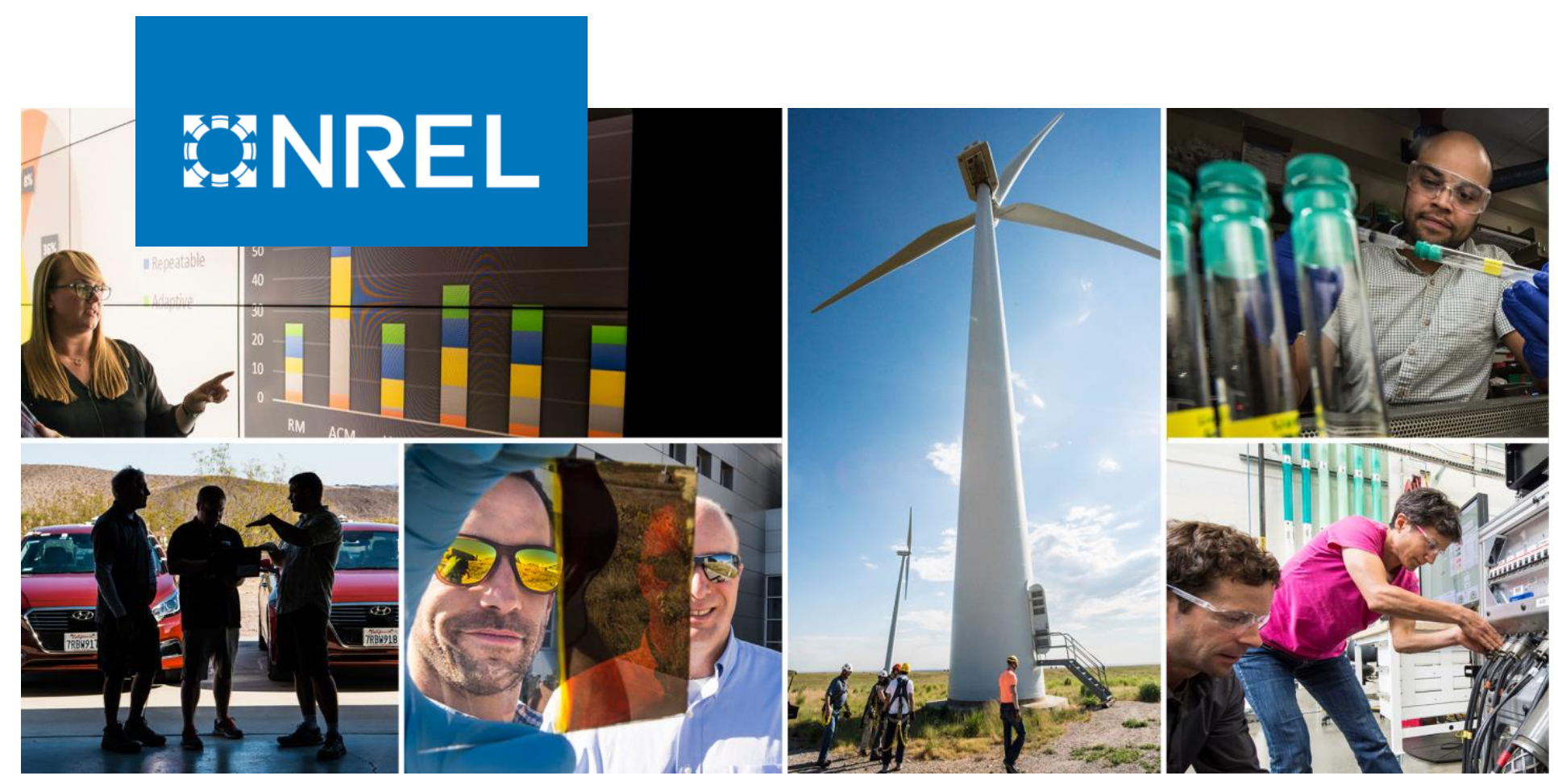

\title{
Collaboration on SBIR/TTO Phase II Project for Optical QC Device and Collaboration on SBIR/TTO Phase II-b Project for Advanced Quality Inspection Device Development
}

Cooperative Research and Development Final Report

CRADA Number: CRD-16-00652

NREL Technical Contact: Michael Ulsh

NREL is a national laboratory of the U.S. Department of Energy Office of Energy Efficiency \& Renewable Energy

Operated by the Alliance for Sustainable Energy, LLC

This report is available at no cost from the National Renewable Energy Laboratory (NREL) at www.nrel.gov/publications.
Technical Report

NREL/TP-5900-80387

June 2021 


\section{FNREL}

\section{Collaboration on SBIR/TTO Phase II Project for Optical QC Device and Collaboration on SBIR/TTO Phase II-b Project for Advanced Quality Inspection Device Development}

\section{Cooperative Research and Development Final Report}

\section{CRADA Number: CRD-16-00652}

NREL Technical Contact: Michael Ulsh

\section{Suggested Citation}

Ulsh, Michael. 2021. Collaboration on SBIR/TTO Phase II Project for Optical QC Device and Collaboration on SBIR/TTO Phase II-b Project for Advanced Quality Inspection Device Development: Cooperative Research and Development Final Report, CRADA Number CRD-16-00652. Golden, CO: National Renewable Energy Laboratory. NREL/TP- 5900-80387. https://www.nrel.gov/docs/fy21osti/80387.pdf.

NREL is a national laboratory of the U.S. Department of Energy Office of Energy Efficiency \& Renewable Energy Operated by the Alliance for Sustainable Energy, LLC

This report is available at no cost from the National Renewable Energy Laboratory (NREL) at www.nrel.gov/publications.

Contract No. DE-AC36-08GO28308
Technical Report NREL/TP-5900-80387 June 2021

National Renewable Energy Laboratory 15013 Denver West Parkway Golden, CO 80401 303-275-3000 • www.nrel.gov 


\section{NOTICE}

This work was authored by the National Renewable Energy Laboratory, operated by Alliance for Sustainable Energy, LLC, for the U.S. Department of Energy (DOE) under Contract No. DE-AC36-08GO28308. Funding provided by U.S. Department of Energy Office of Energy Efficiency and Renewable Energy Hydrogen and Fuel Cell Technologies Office. The views expressed herein do not necessarily represent the views of the DOE or the U.S. Government.

This work was prepared as an account of work sponsored by an agency of the United States Government. Neither the United States Government nor any agency thereof, nor any of their employees, nor any of their contractors, subcontractors or their employees, makes any warranty, express or implied, or assumes any legal liability or responsibility for the accuracy, completeness, or any third party's use or the results of such use of any information, apparatus, product, or process disclosed, or represents that its use would not infringe privately owned rights. Reference herein to any specific commercial product, process, or service by trade name, trademark, manufacturer, or otherwise, does not necessarily constitute or imply its endorsement, recommendation, or favoring by the United States Government or any agency thereof or its contractors or subcontractors. The views and opinions of authors expressed herein do not necessarily state or reflect those of the United States Government or any agency thereof, its contractors or subcontractors.

This report is available at no cost from the National Renewable Energy Laboratory (NREL) at www.nrel.gov/publications.

U.S. Department of Energy (DOE) reports produced after 1991 and a growing number of pre-1991 documents are available free via www.OSTI.gov.

Cover Photos by Dennis Schroeder: (clockwise, left to right) NREL 51934, NREL 45897, NREL 42160, NREL 45891, NREL 48097, NREL 46526.

NREL prints on paper that contains recycled content. 


\section{Cooperative Research and Development Final Report}

\section{Report Date: June 23, 2021}

In accordance with requirements set forth in the terms of the CRADA agreement, this document is the CRADA final report, including a list of subject inventions, to be forwarded to the DOE Office of Scientific and Technical Information as part of the commitment to the public to demonstrate results of federally funded research.

Parties to the Agreement: Mainstream Engineering Corporation

CRADA Number: CRD-16-00652

CRADA Title: Collaboration on SBIR/TTO Phase II Project for Optical QC Device and Collaboration on SBIR/TTO Phase II-b Project for Advanced Quality Inspection Device Development

Responsible Technical Contact at Alliance/ National Renewable Energy Laboratory (NREL):

Michael Ulsh | michael.ulsh@nrel.gov

Name and Email Address of POC at Company:

Andrew Wagner | awagner@mainstream-engr.com

\section{Sponsoring DOE Program Office(s):}

- Office of Energy Efficiency and Renewable Energy (EERE) Hydrogen and Fuel Cell Technologies Office (HFTO)

- Small Business Administration (SBA) Small Business Innovation Research (SBIR) and Small Business Technology Transfer (STTR) Programs

Joint Work Statement Funding Table showing DOE commitment:

\begin{tabular}{|c|c|}
\hline Estimated Costs & $\begin{array}{c}\text { NREL Shared Resources } \\
\text { a/k/a Government In-Kind }\end{array}$ \\
\hline Year 1 & $\$ 60,529.00$ \\
Year 2 & $\$ 29,392.00$ \\
Year 3 & $\$ 130,044.00$ \\
Year 4 & $\$ 119,956.00$ \\
\hline TOTALS & $\$ 339,921.00$ \\
\hline
\end{tabular}




\section{Executive Summary of CRADA Work:}

The overall goal of this program is to develop and commercialize a turnkey quality control solution for the entire PEM fuel cell manufacturing process including membrane, gas diffusion layers, catalyst, and assembled systems. This quality control solution is unique to each customer's specific needs but includes a suite of in-line quality control systems for roll-to-roll manufacturing that can target thin, transparent membrane as well as opaque membrane, catalyst, and GDLs. The Phase II developed the CPNUVV system for thin, transparent membrane that operates using polarized filters to enhance defect resolution and determine thickness. However, PEM material manufacturers want a complete, turnkey solution for all components of the PEM fuel cell. In the Phase IIB, Mainstream will partner with NREL, and transition reflectance technology NREL developed (US Patent 9,234,843) to operate in real-time on a web-line to develop a total solution to PEM quality control. The device will identify and mark defects as well as monitor materials thickness in real-time to improve line efficiency and to reduce waste.

The research performed at NREL under this CRADA increases the basis of knowledge about optical inspection methods, how they perform with regards to fuel cell component materials, and how they can be implemented in in-line, real-time configurations to provide quality inspection for roll-to-roll (R2R) manufacturing. Methods explored were found to be sensitive to catalyst loading in electrodes on both membrane and gas diffusion media substrates and to membrane thickness, across a broad range of thickness. The latter capability is novel and now patented and provides a previously unstudied and undemonstrated capability for R2R manufacturing of membranes.

\section{Summary of Research Results:}

\section{CRADA Part 1: Collaboration on SBIR/TTO Phase II Project for Optical QC Device}

A new real-time, high-efficiency inspection system is required to reach fuel cell manufacturing quality targets and overcome the Department of Energy (DOE) barriers of a lack of improved methods of final inspection of membrane electrode assemblies (MEAs) and low levels of quality control. NREL assisted Mainstream Engineering, in their Phase I project, in demonstrating a prototype inspection system that was based in part on NREL's optical inspection technology. In this Phase II project, NREL will continue to assist Mainstream in developing and demonstrating a full-scale inspection device, as well as performing studies, with NREL's subcontractor, Georgia Tech (GT), to further understand the effects of inhomogeneities of different type and size in membrane materials.

\section{TASK 1:}

NREL, in collaboration with GT, will create several membrane samples with natural or artificially induced defects. Reinforced and multi-component membranes will be a particular point of emphasis for this task. The defects will be characterized by type and size and provided to Mainstream for single blind validation of the prototype system. NREL will use existing test platforms (e.g., our fuel cell scanner system) for this work. 


\section{$\underline{\text { Results for Task 1: }}$}

Through a series of membrane casting experiments, GT, who is a sub to NREL on the project, fabricated a large set of membrane samples. These experiments were run on GT's roll-to-roll (R2R) slot die casting equipment. Figure 1 shows an image of the GT casting die. A leader in polymer casting process window studies, the GT group purposefully cast Nafion ionomer films both inside and outside the casting window of stability in order to fabricate both pristine and defected samples. Membranes of between approximately 25 and $50 \mu \mathrm{m}$ in thickness were fabricated across a broad range of casting conditions. Figures 2-4 show the process conditions for this series of three casting experiments. A great variety of defect types, including pinholes, air bubbles, scratches, cracks, various areal surface effects, and included contaminants, as well as sizes, from several hundred to over a thousand $\mu \mathrm{m}$ in diameter or length, were created. NREL performed optical microscopy on many of these defects to further characterize their morphology and size (see examples below in Results for Task 3 section). An extensive set of these membrane samples, both pristine and defected, were provided to Mainstream for testing using their optical technique. [Q2-17]

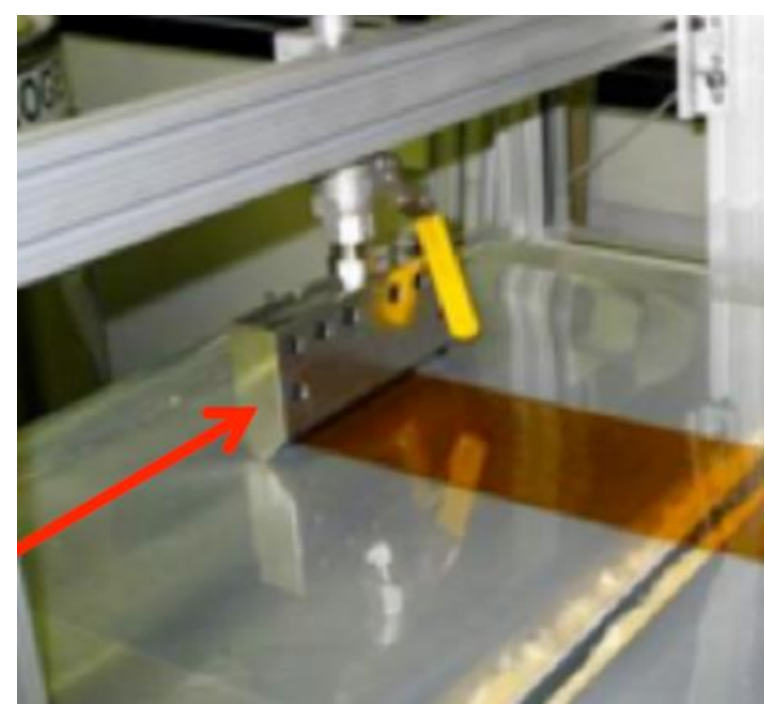

Figure 1. GT polymer casting die. 


\begin{tabular}{|c|c|c|c|c|c|c|c|c|c|}
\hline Sample No & $\begin{array}{l}\text { Slot gap } \\
\text { ( } \mu \mathrm{m})\end{array}$ & $\begin{array}{c}\text { Coating gap } \\
\text { ( } \mu \mathrm{m})\end{array}$ & $\begin{array}{l}\text { Effective } \\
\text { discharge } \\
\left(\mathrm{mm}^{2} / \mathrm{s}\right)\end{array}$ & $\begin{array}{l}\text { Discharge } \\
\text { (mL/min) }\end{array}$ & $\begin{array}{c}\text { Substrate } \\
\text { speed } \\
\text { (mm/s) }\end{array}$ & $\begin{array}{c}\text { Wet film } \\
\text { thickness } \\
\quad(\mu \mathrm{m})\end{array}$ & $\begin{array}{c}\text { Solid film } \\
\text { thickness } \\
\text { ( } \mu \mathrm{m})\end{array}$ & $\begin{array}{l}\text { Defect/ } \\
\text { Pristine }\end{array}$ & Remark \\
\hline 101 & 250 & 165 & 3.7 & 22.7 & 25.0 & 150 & 20 & $P$ & \\
\hline 102 & 250 & 180 & 3.7 & 22.7 & 25.0 & 150 & 20 & P & \\
\hline 103 & 250 & 165 & 4.5 & 27.4 & 30.0 & 150 & 20 & $\mathbf{P}$ & \\
\hline 104 & 250 & 300 & 2.5 & 15.2 & 10.0 & 250 & 30 & $\mathbf{P}$ & \\
\hline 105 & 250 & 320 & 3.0 & 18.2 & 10.0 & 300 & 40 & $P$ & \\
\hline 106 & 250 & 270 & 2.5 & 15.2 & 10.0 & 250 & 30 & $P$ & \\
\hline 107 & 250 & 300 & 2.5 & 15.2 & 10.0 & 250 & 30 & $\mathbf{P}$ & \\
\hline 108 & 250 & 370 & 3.5 & 21.3 & 10.0 & 350 & 40 & $P$ & \\
\hline 109 & 250 & 400 & 7.0 & 42.6 & 20.0 & 350 & 40 & $\mathbf{P}$ & \\
\hline 110 & 250 & 325 & 7.5 & 45.7 & 25.0 & 300 & 40 & D & 9h: air-bubble \\
\hline 111 & 250 & 325 & 7.5 & 45.7 & 25.0 & 300 & 40 & $P$ & \\
\hline 112 & 250 & 325 & 9.0 & 54.8 & 30.0 & 300 & 40 & D & 10i: air-bubble \\
\hline 113 & 250 & 325 & 9.0 & 54.8 & 30.0 & 300 & 40 & $P$ & \\
\hline 114 & 250 & 370 & 10.5 & 64.0 & 30.0 & 350 & 40 & $\mathrm{D}$ & $58,68,10 i:$ air-bubble \\
\hline 115 & 250 & 440 & 20.0 & 122.0 & 50.0 & 400 & 50 & D & $\begin{array}{l}\text { 12d: small bubble } n \text { crack } \\
171,18 \mathrm{n}, 180 \text { : air-bubble }\end{array}$ \\
\hline 116 & 250 & 440 & 20.0 & 122.0 & 50.0 & 400 & 50 & D & $\begin{array}{l}\text { 10e: small bubble } n \text { crack } \\
19 \mathrm{~g}, 19 \mathrm{j}, 19 \mathrm{~d} \text { : air-bubble }\end{array}$ \\
\hline 117 & 250 & 440 & 20.0 & 122.0 & 50.0 & 400 & 50 & $\mathrm{D}$ & 3b, 4j, 2s, 2h: air-bubble \\
\hline 118 & 250 & 440 & 19.7 & 120.2 & 49.2 & 400 & 50 & D & $\begin{array}{l}\text { 5C: Air-bubble } \\
\text { 6C: Air-bubble }\end{array}$ \\
\hline 119 & 250 & 440 & 19.7 & 120.2 & 49.2 & 400 & so & D & $\begin{array}{l}\text { 2e:Air-bubble } \\
\text { 14r: Air-bubble }\end{array}$ \\
\hline 120 & 250 & 440 & 24.1 & 147.3 & 60.4 & 400 & 50 & D & Sn: small bubble $n$ crack \\
\hline 121 & 250 & 440 & 24.1 & 147.3 & 60.4 & 400 & 50 & $P$ & \\
\hline 122 & 250 & 440 & 27.7 & 169.3 & 69.4 & 400 & 50 & $P$ & \\
\hline 123 & 250 & 440 & 27.7 & 169.3 & 69.4 & 400 & 50 & $P$ & \\
\hline 124 & 250 & 440 & 27.7 & 169.3 & 69.4 & 400 & 50 & $P$ & \\
\hline 125 & 250 & 420 & 15.3 & 93.4 & 38.3 & 400 & 50 & D & $\begin{array}{l}\text { 91: contamination } \\
\text { Sb: crack }\end{array}$ \\
\hline 126 & 250 & 420 & 15.3 & 93.4 & 38.3 & 400 & 50 & D & 18d: contamination \\
\hline 127 & 250 & 440 & 20.0 & 121.9 & 50.0 & 400 & 50 & $\mathbf{P}$ & \\
\hline 128 & 250 & 325 & 9.0 & 54.8 & 30.0 & 300 & 40 & $P$ & \\
\hline
\end{tabular}

Figure 2. 100 series membrane samples and conditions.

\begin{tabular}{|c|c|c|c|c|c|c|c|c|c|c|c|c|}
\hline $\begin{array}{c}\text { Sample } \\
\text { No }\end{array}$ & $\begin{array}{l}\text { Slot } \\
\text { gap } \\
(\mu \mathrm{m})\end{array}$ & $\begin{array}{c}\text { Costing } \\
\text { gap } \\
(\mu \mathrm{m})\end{array}$ & $\begin{array}{l}\text { Effective } \\
\text { discharge } \\
\left(\mathrm{mm}^{2} / \mathrm{s}\right)\end{array}$ & $\begin{array}{l}\text { Discharge } \\
\text { (mL/min) }\end{array}$ & $\begin{array}{l}\text { Substrate } \\
\text { speed } \\
(\mathrm{mm} / \mathrm{s})\end{array}$ & $\begin{array}{c}\text { Wet film } \\
\text { thickness } \\
(\mu \mathrm{m})\end{array}$ & $\begin{array}{c}\text { Solid film } \\
\text { thickness } \\
(\mu \mathrm{m})\end{array}$ & $\begin{array}{l}\text { Defect/ } \\
\text { Pristine }\end{array}$ & Date & $\begin{array}{l}\text { Temperature } \\
\text { (C) }\end{array}$ & Humidity & Remark \\
\hline 201 & 250 & 440 & 24.16 & 147.3 & 60.4 & 400 & 50 & $P$ & $1 / 26 / 17$ & 21 & $\sim 8 \%$ & $\begin{array}{l}\text { Significant } \\
\text { Browning of } \\
\text { Sample \& } \\
\text { Smudge due to } \\
\text { Mistake While } \\
\text { Annealing }\end{array}$ \\
\hline 202 & 250 & 440 & 20 & 121.9 & 50 & 400 & 50 & $P$ & $2 / 10 / 17$ & 22 & $40 \%$ & $\begin{array}{l}\text { Air bubbles } \\
\text { (Run 127) }\end{array}$ \\
\hline 204 & 250 & 440 & 20.02 & 122 & 50 & 400 & 50 & $P$ & $3 / 4 / 17$ & 21 & $16 \%$ & $\begin{array}{l}\text { Air bubbles } \\
\text { (Run 115) }\end{array}$ \\
\hline 205 & 250 & 440 & 20.02 & 122 & 50 & 400 & 50 & D & $3 / 8 / 17$ & 21 & $27 \%$ & $\begin{array}{l}\text { Air bubbles } \\
\text { (Run 116) }\end{array}$ \\
\hline 206 & 250 & 440 & 20.02 & 120.2 & 49.2 & 400 & 50 & D & $3 / 8 / 17$ & 21 & $27 \%$ & $\begin{array}{l}\text { Air bubbles } \\
\text { (Run 117) }\end{array}$ \\
\hline 207 & 250 & 440 & 20.02 & 122 & 50 & 400 & 50 & D & $3 / 12 / 17$ & 20 & $36 \%$ & $\begin{array}{l}\text { Air bubbles } \\
\text { (Run 116) }\end{array}$ \\
\hline
\end{tabular}

Figure 3. 200 series membrane samples and conditions. 


\begin{tabular}{|c|c|c|c|c|c|c|c|c|c|c|c|}
\hline $\begin{array}{l}\text { Sample } \\
\text { No. }\end{array}$ & $\begin{array}{l}\text { Slot } \\
\text { Gap } \\
(\mu \mathrm{m})\end{array}$ & $\begin{array}{c}\text { Coating } \\
\text { Gap } \\
(\mu \mathrm{m})\end{array}$ & $\begin{array}{c}\text { Effective } \\
\text { Discharge } \\
\left(\mathrm{mm}^{2} / \mathrm{s}\right)\end{array}$ & $\begin{array}{l}\text { Discharge } \\
\text { (mL/min) }\end{array}$ & $\begin{array}{c}\text { Substrate } \\
\text { Speed } \\
(\mathrm{mm} / \mathrm{s})\end{array}$ & $\begin{array}{l}\text { Wet Film } \\
\text { Thickness } \\
(\mu \mathrm{m})\end{array}$ & $\begin{array}{l}\text { Solid Film } \\
\text { Thickness } \\
(\mu \mathrm{m})\end{array}$ & $\begin{array}{l}\text { Defect/ } \\
\text { Pristine }\end{array}$ & $\begin{array}{l}\text { Ambient } \\
\text { Temp } \\
\left({ }^{\circ} \mathrm{C}\right)\end{array}$ & $\begin{array}{l}\text { Ambient } \\
\text { Humidity }\end{array}$ & Remark \\
\hline 301 & 250 & 300 & 2.5 & 15.2 & 10.0 & 250 & 30 & D & & & Contaminated sample \\
\hline 302 & 250 & 250 & 2.514 & 15.24 & 12.57 & 200 & 25 & D & 21.5 & $8 \%$ & Contaminated sample \\
\hline 303 & 250 & 250 & 2.514 & 15.24 & 12.57 & 200 & 25 & D & 22 & $40 \%$ & Slightly cloudy sample \\
\hline 304 & 250 & 300 & 2.5 & 15.24 & 10 & 250 & 30 & D & 21 & $52 \%$ & Cloudy Sample \\
\hline 305 & 250 & 250 & 2.514 & 15.24 & 12.57 & 200 & 25 & D & 21 & $52 \%$ & Cloudy Sample \\
\hline 306 & 250 & 370 & 10.5 & 64 & 30 & 350 & 40 & D & 21 & $16 \%$ & $\begin{array}{c}\text { Air Bubbles (114 } \\
\text { recreate) }\end{array}$ \\
\hline $307^{*}$ & 250 & 325 & 9 & 54.8 & 30 & 300 & 40 & D & 21 & $27 \%$ & $\begin{array}{l}\text { Air Bubbles and } \\
\text { Thickness Variations } \\
\text { (117 recreate) }\end{array}$ \\
\hline 308 & 250 & 440 & 20 & 122.0 & 50 & 400 & 50 & D & 20 & $36 \%$ & $\begin{array}{c}\text { Air Bubbles and } \\
\text { extensive break lines/ } \\
\text { streaking (New nafion } \\
\text { shipment used) (116 } \\
\text { recreate) }\end{array}$ \\
\hline
\end{tabular}

Figure 4. 300 series membrane samples and conditions.

In addition to the solution cast membrane samples, GT used commercially available Nafion membrane materials and applied electron beam lithography (EBL) to enable the creation of much smaller pinhole defects with high precision. EBL-drilled pinholes of 10, 50, and $100 \mu \mathrm{m}$ diameter were fabricated in standard Nafion films. Figure 5 shows microscopy of a membrane sample with a $10 \mu \mathrm{m}$ EBL-drilled pinhole. Several of these samples were provided to Mainstream for testing of their technique. [Q2-17]

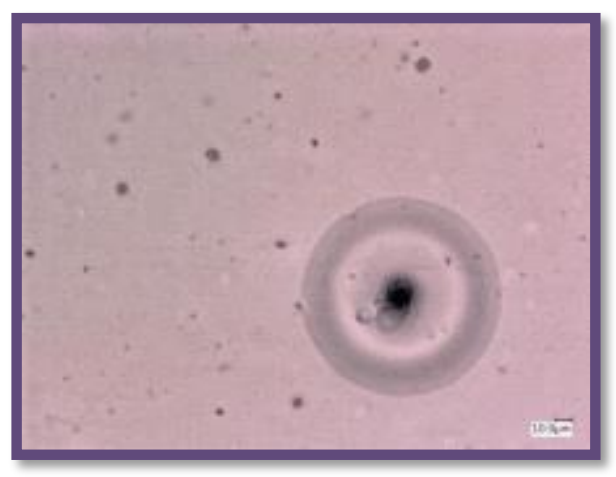

Figure 5. Membrane sample with EBL-drilled $10 \mu \mathrm{m}$ pinhole.

Beyond the samples fabricated at GT, NREL developed an apparatus and technique to repeatably fabricate pinholes in membranes. Figure 6 shows the apparatus, which consists of a membrane sample holder, a micrometer-scale tool for forming the hole, a translation stage with micrometerscale positioning control, and a microscope to view the tool as it is being manually controlled in its motion into the membrane to form the pinhole. Tools of 25,120 , and $250 \mu \mathrm{m}$ in diameter were utilized. Several samples of standard Nafion membranes with fabricated pinholes using this apparatus were provided to Mainstream for testing of their technique. [Q3-17] 


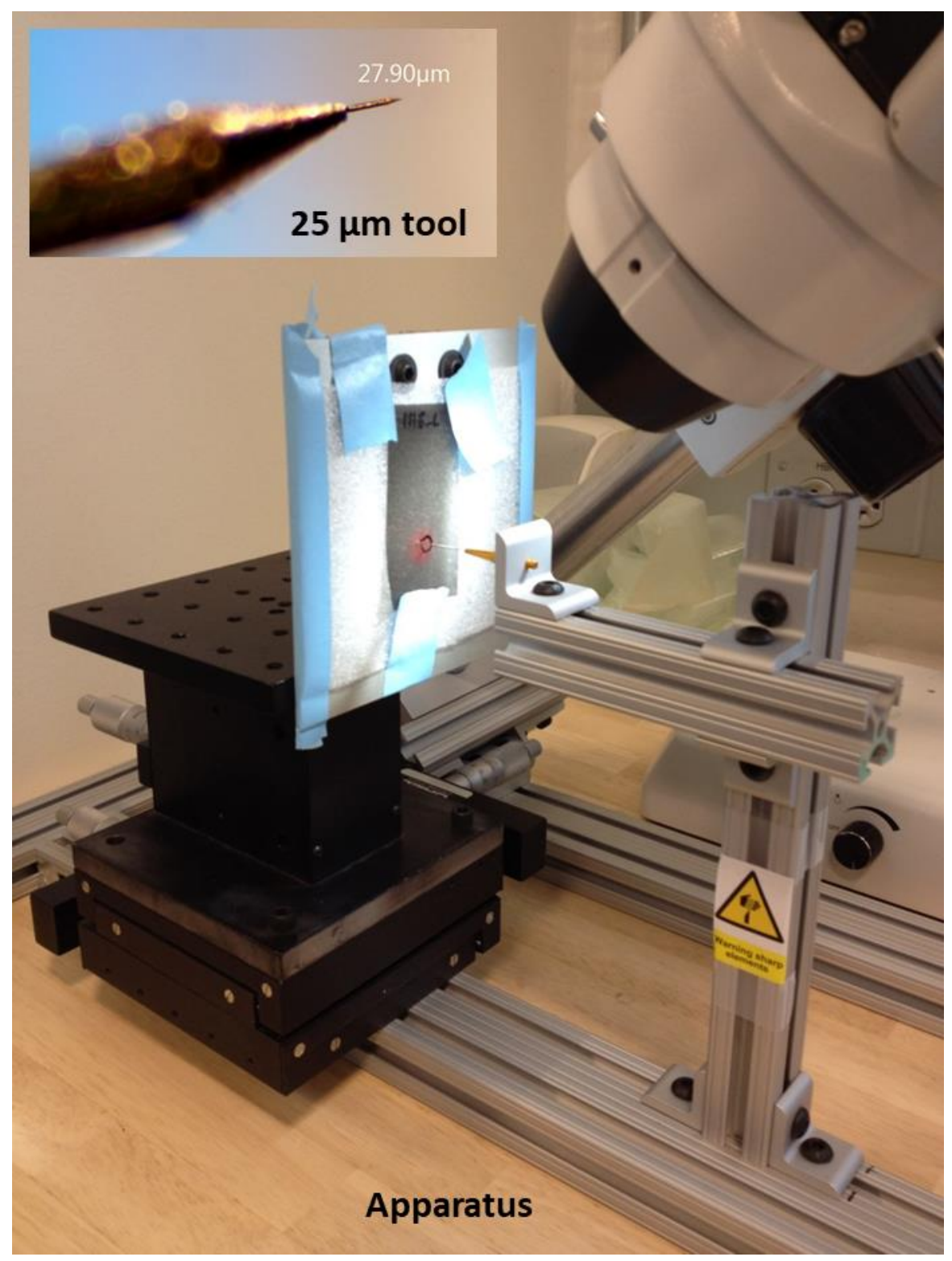

Figure 6. Membrane pinhole fabrication apparatus at NREL.

In summary for Task 1, GT and NREL utilized various methods to fabricate membranes with defects, in some cases leveraging actual as-cast membranes fabricated under unstable conditions and in some cases using already fabricated membranes and creating defects via energetic or mechanical means. A wide range of types and sizes of defects were created and supplied to Mainstream for using in testing and validating their inspection technique. 


\section{TASK 2:}

At Mainstream's direction, NREL will provide technical assistance regarding system integration of Mainstream's prototype measurement system, based on NREL's long experience with in-line diagnostics. NREL will coordinate closely with Mainstream to ensure that intellectual property (beyond NREL's existing patent application) is managed properly. If Mainstream decides that discussions are desired where new IP may be created, NREL and Mainstream will pursue a collaborative agreement that will define a new IP management strategy.

\section{Results for Task 2:}

Mainstream did not request any technical assistance regarding system integration. No discussions of licensing or IP management were deemed necessary by Mainstream during this phase of the collaboration.

\section{TASK 3:}

NREL will determine the effect of membrane defect type and size on fuel cell performance to identify the minimum defect size/type that lead to cell failure. These criteria will be used to help determine the necessary limits of detection for Mainstream's prototype measurement system.

\section{$\underline{\text { Results for Task 3: }}$}

In addition to providing samples of the fabricated defected membranes to Mainstream for their use in the development of their optical techniques, as discussed in the Task 1 section above, NREL performed in situ electrochemical testing of cells assembled with various defected membrane samples to understand the impact of the defects on device performance. As a first step, many cells were fabricated with defected cast membranes from GT, and the hydrogen crossover $(\mathrm{H} 2 \mathrm{XO})$ current density was measured. Cells with $\mathrm{H} 2 \mathrm{XO}$ greater than the $2 \mathrm{~mA} / \mathrm{cm} 2$ maximum target for development of new membranes (a DOE standard target) were judged to have significant defects, and further testing was performed. Figure 7 shows a summary of air polarization data for the membranes/cells judged to have significant crossover. The left and right graphs show polarization data at low and high operating humidity, respectively, for samples with membrane defects ranging in size from $\sim 500$ to several thousand $\mu \mathrm{m}$ in characteristic size, and including air bubbles, pinholes, cracks and included foreign particles. Greater impact on performance was observed at low humidity. Also, performance impacts were observed in both the kinetic and mass transport regions. In addition to total cell performance testing, NREL's unique segmented cell system was employed to understand the spatial performance impacts of the different membrane defects. Figure 8 shows optical microscopy of two representative membrane defects from the GT as-cast fabrication studies. These are from samples GT116 (bubble) and GT120 (crack), indicated in Figure 7. Figures 9 and 10 show the spatial performance data resulting from these defects using the segmented cell, represented as differential current density, i.e. for each segment, the difference in performance between the defected cell and a pristine cell is given. Each figure has a top half showing data at low humidity and a bottom half showing data at high humidity. For each set of data the top row of images shows the spatial distribution of performance in the $50 \mathrm{~cm} 2$ cell, where the inlet is at the top left and the outlet is at the bottom right, and each segment of the $11 \times 11$ array of segments is 
approximately $0.4 \mathrm{~cm} 2$. As can be seen in the legends, red coloration indicates that the defected cell performs worse than the pristine cell within that segment. The bottom row of images provides a bar chart of the differential current density along the flowfield of the hardware, where the far left is the inlet, and the far right is the outlet. Here, negative data indicates that the performance in that segment is worse in the case of the defected cell than for the pristine cell. Some segments show performance that is better in the defected cell because a total voltage is demanded of the cell, so certain areas of the cell have to perform at a greater level to make up for the lower performance in the defected segments. For all cases, the spatial performance data is shown at full cell current densities of 1.2, 1.0, 0.6, and $0.2 \mathrm{~A} / \mathrm{cm} 2$. For the bubble defect, it can be observed that the spatial performance impact occurs in essentially one segment (in the upper right corner) of the cell where the defect is located. The impact of the defect is approximately the same at low and high humidity, and the magnitude in the change in local performance increases with increasing current density. The impact is very different in the case of the crack defect. Here, it can be observed that the spatial performance impact is very dispersed around the cell area where the defect is located (upper region, slightly to the right of center). The performance impact is somewhat greater in the high humidity operating case, and again, increases with increasing current density.

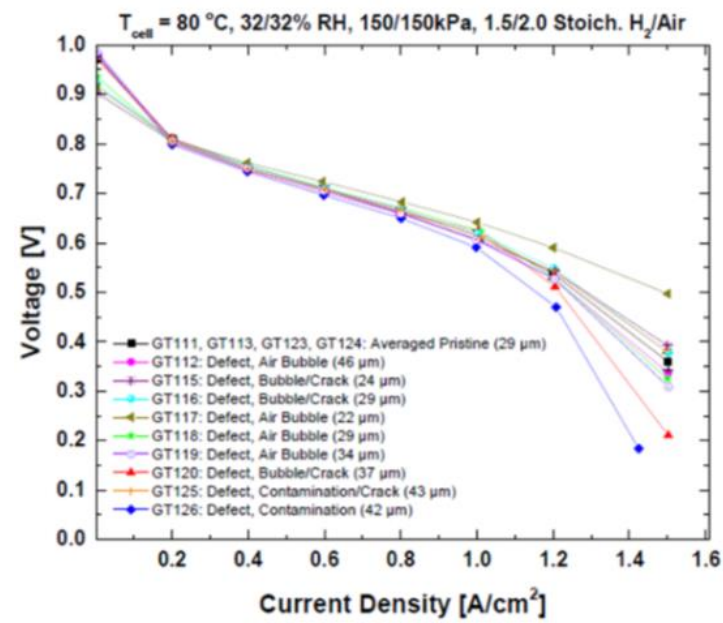

Defect Sizes (from pre-experiment imaging)

- GT112: $3 \mathrm{~mm}$ (linear)

- GT115: $1134 \mu \mathrm{m}$ (diameter)

- GT116: $513 \mu \mathrm{m}$ (diameter)

- GT117: 1342, $1377 \mu \mathrm{m}$ (diameter)

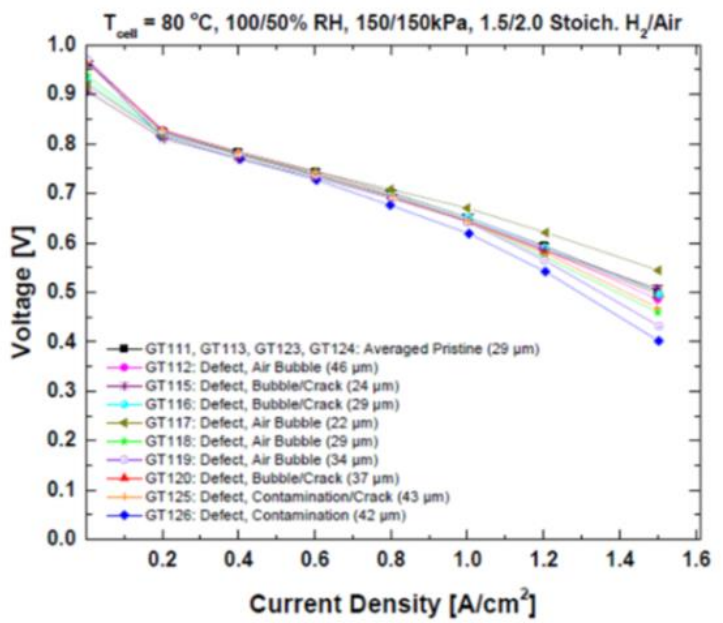

Defect Sizes (from pre-experiment imaging)

- GT118: 662, 1291, $1416 \mu \mathrm{m}$ (diameter)

- GT119: $1429 \mu \mathrm{m}$ (diameter)

- GT120: $819 \mu \mathrm{m}$ (linear)

- GT125: Unable to collect imaging

- GT126: Unable to collect imaging

Figure 7. Air polarization data for selected high-hydrogen-crossover cells having membranes with defects: low (left) and high (right) operating humidity. 

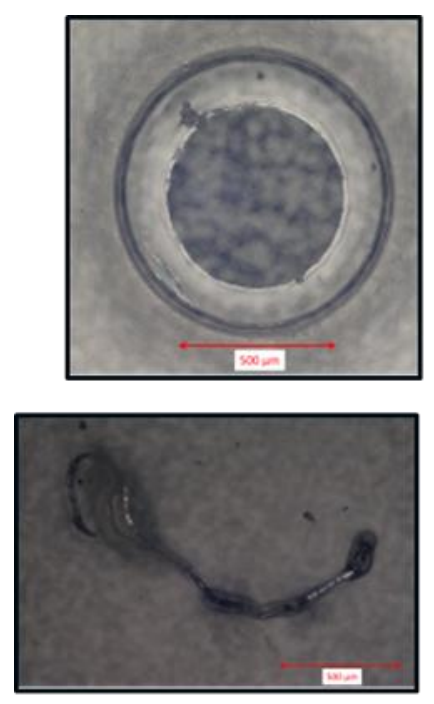

Figure 8. Representative defects from GT as-cast studies: bubble (top) and crack (bottom).

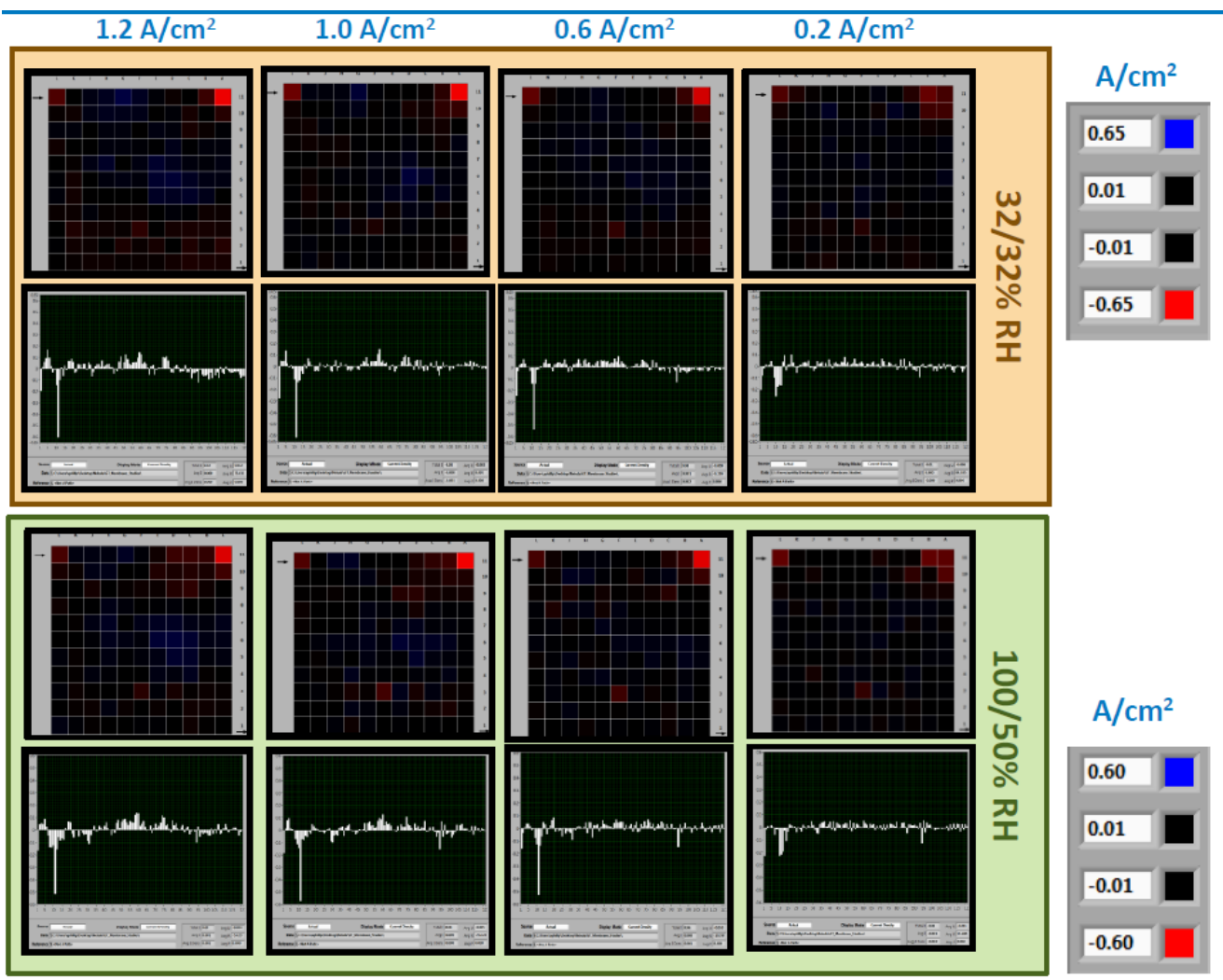

Figure 9. Spatial performance data for the bubble defect in Figure 8, where the defect is located in the upper right corner of the cell. 


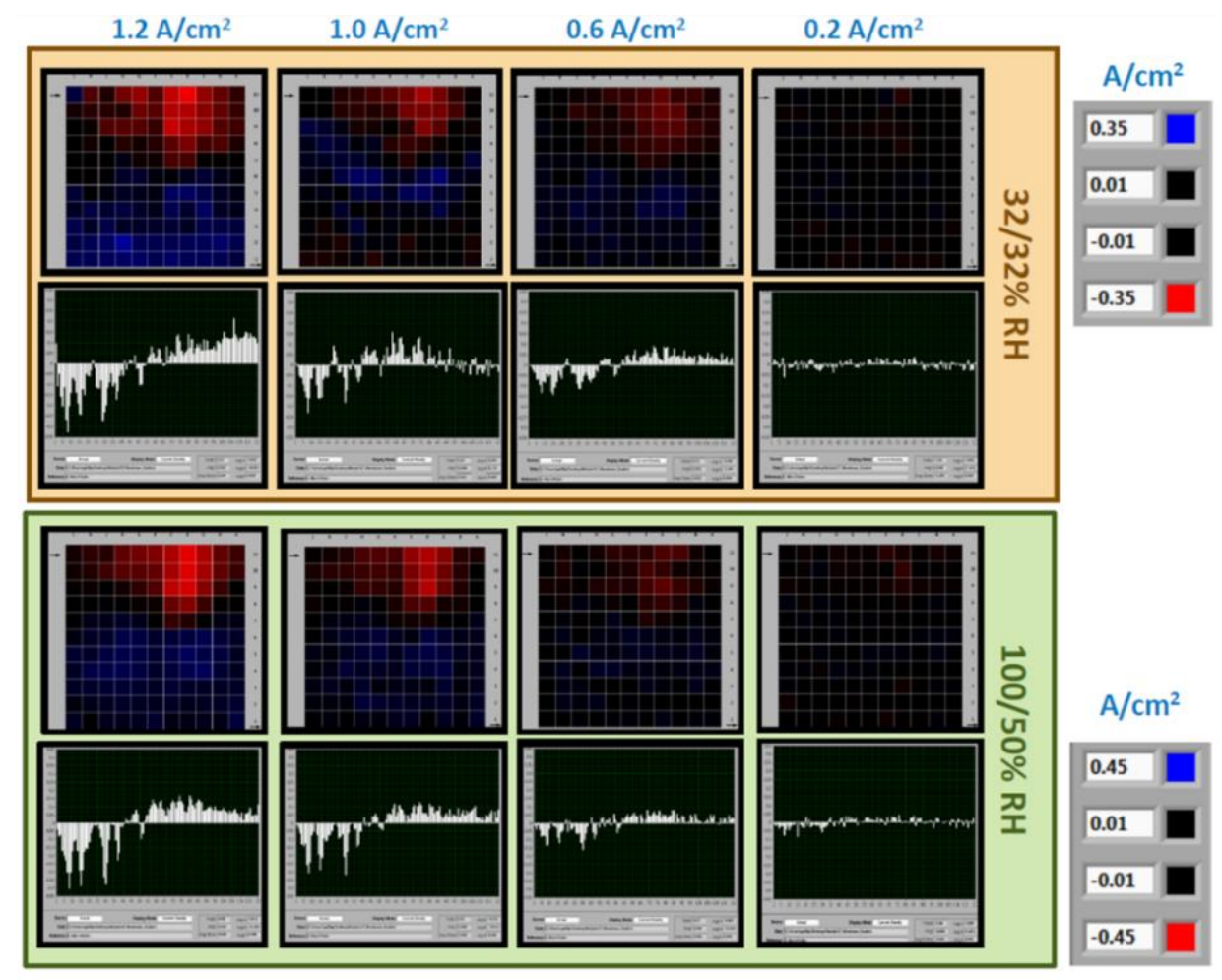

Figure 10. Spatial performance data for the crack defect in Figure 8, where the defect is located in
the upper central area of the cell.

Further leveraging the GT samples, we tested the EBL-drilled membrane sample with a $10 \mu \mathrm{m}$ diameter pinhole (shown in Figure 5). No local or total cell initial performance impact was observed. [Q3-17]

We also tested membranes with pinholes fabricated with the mechanical punching device developed at NREL (shown in Figure 6). Figure 11 shows optical microscopy of a pinhole fabricated in a $50 \mu \mathrm{m}$ thick Nafion membrane using a $120 \mu \mathrm{m}$ diameter tool. Also shown is $\mathrm{x}$-ray computed tomography (XCT) imaging of the pinhole in the fabricated cell (performed at Lawrence Berkeley National Laboratory (LBNL). Total cell polarization data did not show any initial performance impact compared to a pristine cell, as shown in Figure 12. However, using the segmented cell, we did observe local performance differences at the location of the defect. Often, this observation indicates that, while there is no impact on initial cell performance, there may be impact on performance over time. To further explore this possibility, a drive cycle test and a combined chemical/mechanical accelerated stress test (AST) were run on this cell. Figure 13 shows that the defected cell exhibited greater degradation of performance (voltage at 1 $\mathrm{A} / \mathrm{cm} 2$ ) during cycling and faster failure under the AST. Regarding the AST test, we furthermore verified that the failure location of the cell was indeed the location of the pinhole by a quasi-in situ spatial hydrogen crossover testing using infrared thermography. [Q3-18] 

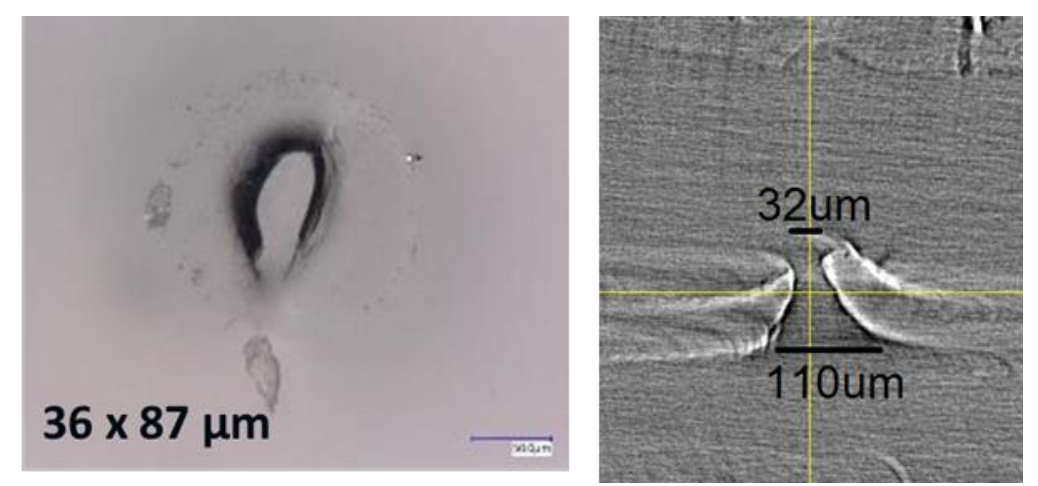

Figure 11. Pinhole sample fabricated at NREL with mechanical punching apparatus: membrane (left), and cell (right).
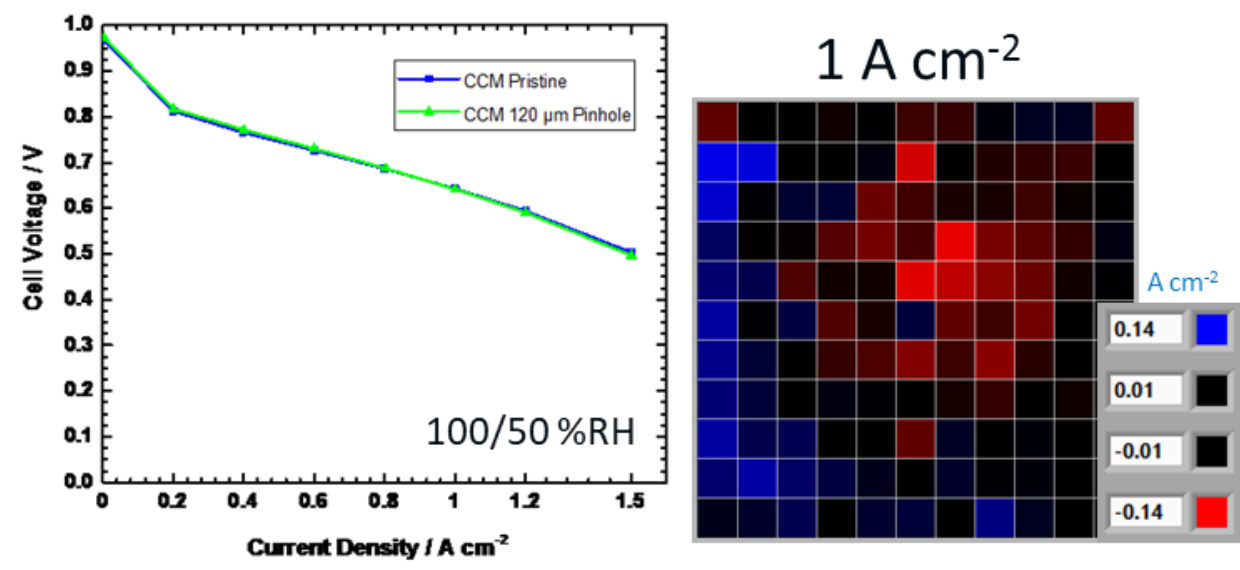

Figure 12. Initial total cell air polarization performance comparison (left) and differential spatial performance (right) of the pinhole cell shown in Figure 11.
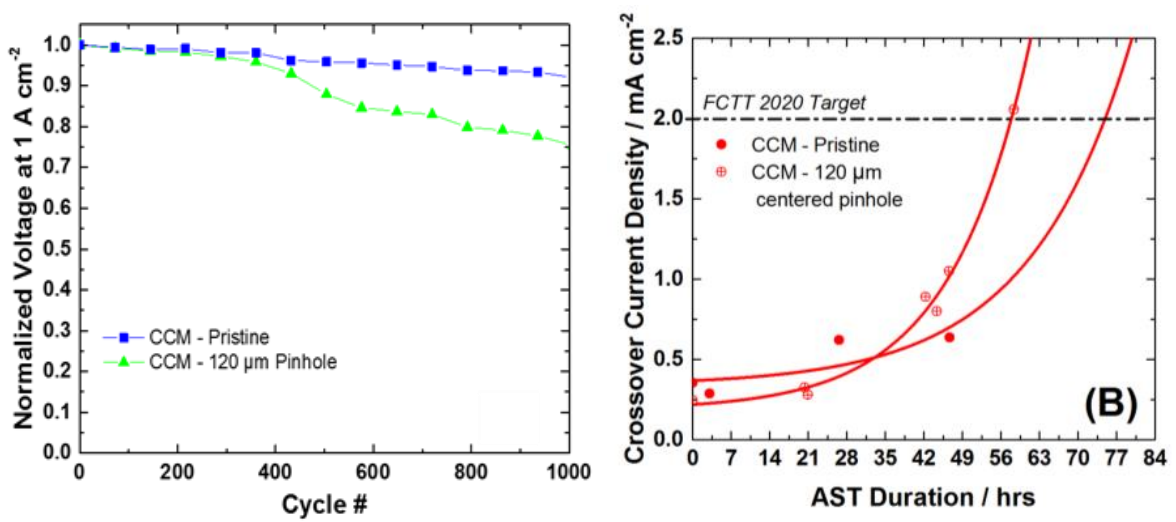

Figure 13. Comparison of performance over time in cycling (left) and time to failure using the AST (right) for the pinhole cell shown in Figure 11.

In summary for Task 3, we observed that pinholes in membrane samples impacted total cell initial performance as a function of pinhole size, where pinholes on the order of 10-100 $\mu \mathrm{m}$ were not seen to cause changes in initial performance, but larger defects on the order of $500-1000 \mathrm{~s} \mu \mathrm{m}$ did cause initial performance changes. We observed local performance impacts of these defects 
in almost all cases. And, for a pinhole of $\sim 50 \mu \mathrm{m}$, we observed degradation in performance over time as well as faster failure in an AST. Thus, defects of this size and type do in fact impact cell performance, especially over time, and ideally in-line inspection tools should be available to cell manufacturers to ensure that materials with these types of defects are not incorporated into fuel cell stacks.

A manuscript documenting the work testing the GT as-cast membranes was published as: Phillips A., Ulsh M., Mackay J., Harris T., Shrivastava N., Chatterjee A., Porter J., Bender G. "The effect of membrane casting irregularities on initial fuel cell performance." Fuel Cells, 20 (1), 60-69, 2020.

\section{TASK 4:}

NREL will coordinate with Mainstream to facilitate and support a demonstration of Mainstream's full-scale prototype system on NREL's research web-line.

\section{Results for Task 4:}

To support Mainstream's ability to validate their technique and hardware in a R2R environment, NREL hosted a visit of the Mainstream PI and collaborators during Q1 of fiscal year 2018 during which Mainstream set up their prototype optical inspection device on NREL's research web-line and ran rolls of many different membrane materials over a range of speed and tension to validate the operation of the prototype QC system. For this first validation experiment, already manufactured commercial and experimental membranes were used. During the following quarter, a second visit was hosted. This time, the optical inspection device was set up on NREL's $\mathrm{R} 2 \mathrm{R}$ coating/casting line. There is an inspection enclosure between the first and second drying ovens on the coating line, and the system was set up in this space, as shown in Figure 14. NREL cast Nafion membranes onto a backer in real time, and data was taken with the inspection system of the as-cast membranes, in both wet and dry states. 


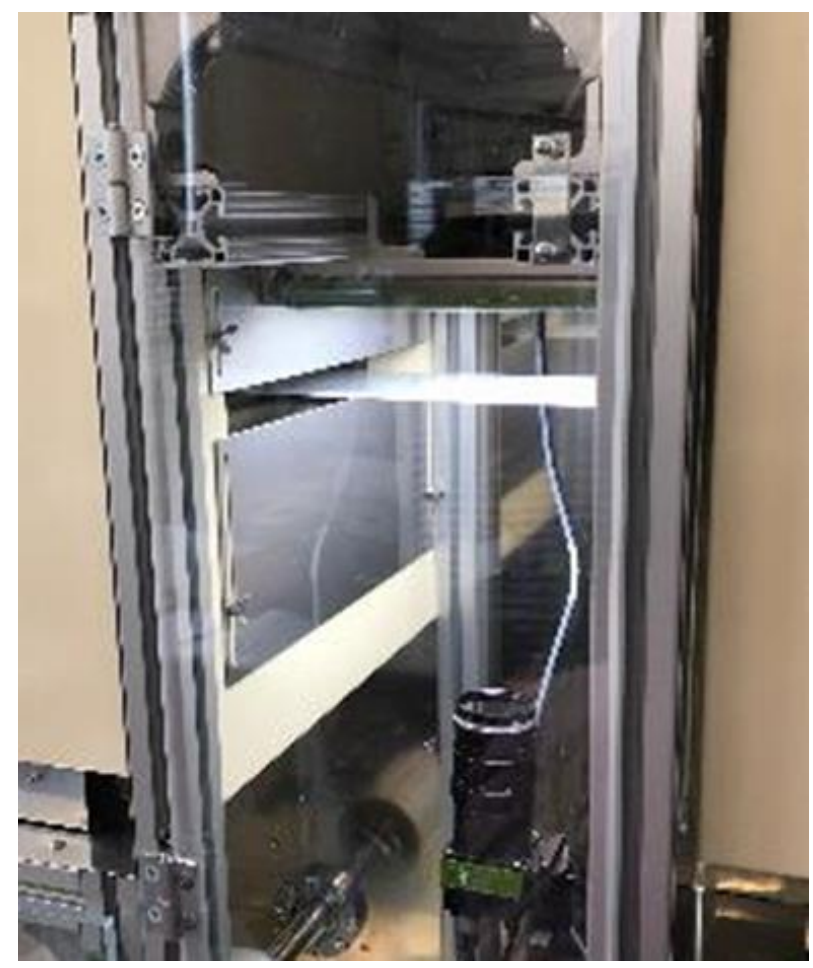

Figure 14. Mainstream prototype inspection system set up on NREL's coating line, here shown inspecting an as-cast membrane.

During Part 1 of the CRADA, NREL provided monthly reporting of progress to Mainstream via written reports.

\section{CRADA Part 2: Collaboration on SBIR/TTO Phase II-b Project for Advanced Quality Inspection Device Development}

A new real-time, high-efficiency inspection system is required to reach fuel cell manufacturing quality targets and overcome DOE barriers of a lack of improved methods of final inspection of membrane electrode assemblies (MEAs) and low levels of quality control. NREL assisted Mainstream Engineering, in their Phase I and Phase II projects, in demonstrating a prototype inspection system that was based in part on NREL's optical inspection technology. In this Phase II-b project, NREL will continue to assist Mainstream in developing and demonstrating a fullscale inspection device. This assistance will include development of multispectral, e.g. optical, infrared, and hyperspectral, techniques for real-time inspection; creation of simulated or asfabricated defect samples; providing access to and assistance with NREL's roll-to-roll web-lines for demonstrations of device prototypes; and studies to further understand the effects of inhomogeneities of different type and size in MEA materials.

\section{TASK 1: Develop real-time multispectral techniques}

NREL will utilize existing and developmental test beds to explore the real-time inspection of opaque materials, namely electrodes, membranes, catalyst coated membranes, gas diffusion media, and multi-layer assemblies. These studies will focus on small-scale development and demonstration, and elucidation of sensitivity, accuracy, resolution, speed, etc. of the different 
techniques. Properties of interest include porosity, thickness, catalyst loading, defects, and composition. Techniques with a particular focus will include optical loading imaging, infrared imaging, and hyperspectral imaging. NREL will provide information on methods, test results, and lessons learned for these techniques, along with the more established optical reflectance technique, to Mainstream as appropriate to support technology transition.

\section{$\underline{\text { Results for Task 1: }}$}

Subsequent to the execution of the Phase II-b CRADA, Mainstream and NREL determined that the primary focus of the inspection method development effort (Task 1) at NREL should continue to be on novel techniques for transparent membrane substrates, understanding aspects relate especially to areal thickness measurement as well as the impact of equipment configuration and measurement conditions.

To support this primary effort at NREL, we completed the design, construction, and operational verification of an experimental testbed to facilitate studies of membrane thickness imaging. NREL's hyperspectral camera, which covers a wavelength range from the far-UV to near-IR, was mounted on NREL's research web-line on the dedicated optical inspection apparatus. Studies were performed to understand the impact of different alignment and configuration aspects, and hardware was set up for data acquisition and storage for the massive amount of realtime data that is captured. Then, polymer membranes of various thickness and type were run on the web-line. Hyperspectral data was acquired and processed to generate thickness maps. In the example provided in Figure 15, a reinforced fuel cell membrane was imaged using the technique. The data shows both cross-web and down-web variations in the sample thickness and indicates sub-micron sensitivity. The pixel-by-pixel spectral data undergoes Fourier transform and then a peak-finding algorithm to identify the thickness. Our peak-finding algorithm was sub-optimal at this point in the effort, leading to the white spots in the image (where no peak, and thus no thickness, was identified). [Q4-18] 


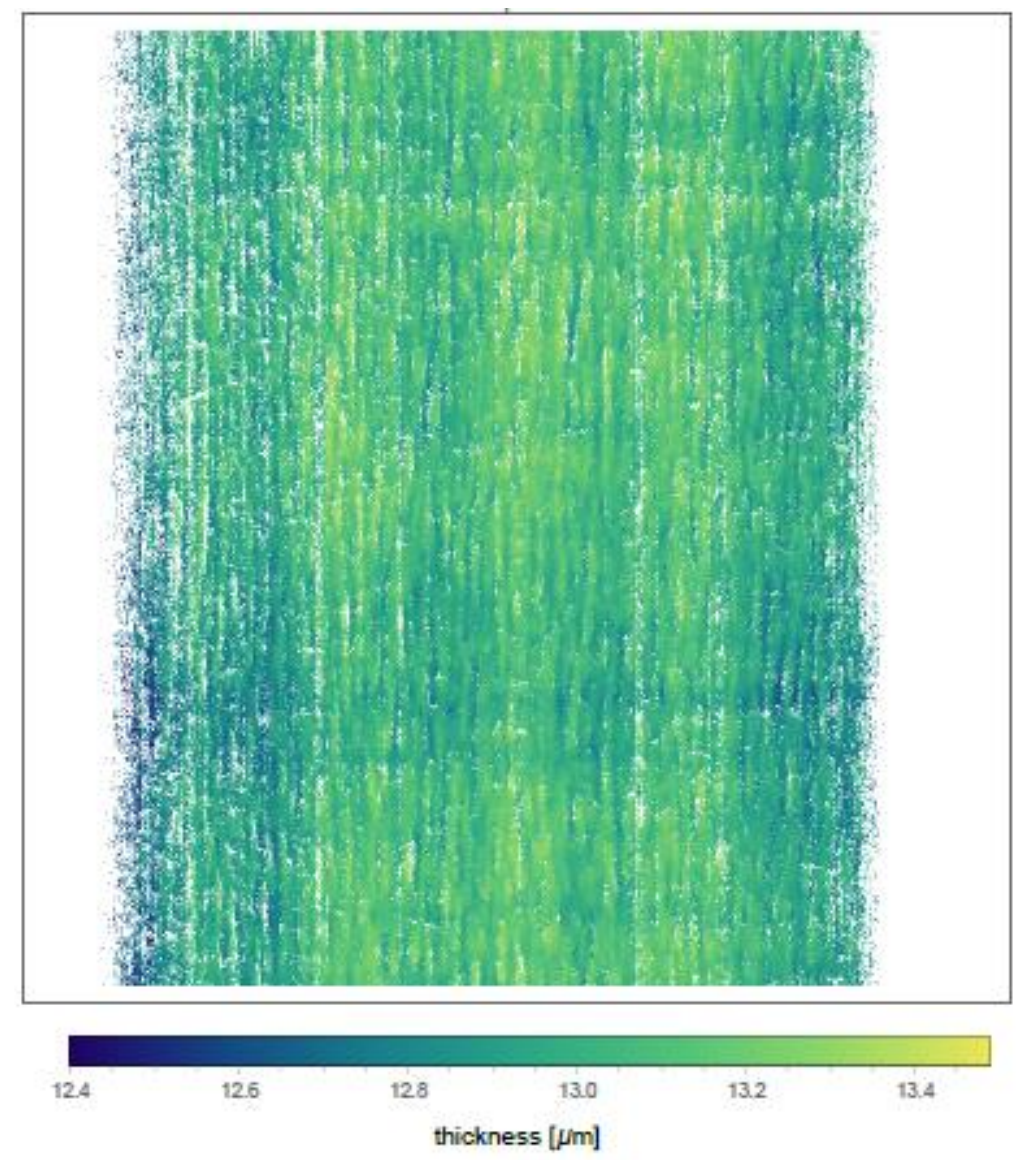

Figure 15. Thickness mapping of reinforced fuel cell membrane.

In addition to effort in the development of the hyperspectral imaging inspection itself, NREL completed work on the development of a new graphics-processing-unit(GPU)-based processing algorithm for the extremely high data acquisition volume case of running the hyperspectral camera real-time on the web-line. This new methodology was shown to be 70 times faster than the previous method. [Q3-19]

Continuing the development and validation of the hyperspectral imaging technique for membrane thickness mapping, a second web-line experiment was run, including 11 different polymer membranes from three different suppliers, combinations of which were run in 17 separate runs, leading to over $11 \mathrm{~TB}$ of imaging data gathered. In one example of the results, Figure 16 shows imaging of a long section of a fuel cell membrane. The color contour graphs show the thickness imaging of consecutive sections of the total membrane length stacked for presentation. As can be seen in the cross-web line data at the left, the thickness variation in that direction is quite uniform and very small, less than $1 \mu \mathrm{m}$. The down-web line data at the bottom (from the third contour plot section from the bottom) shows that the thickness in that direction is extremely uniform. The conclusions from this second web-line demonstration were: (a) good imaging results were obtained for all single-layer and several multi-layer membranes less than 30 $\mu \mathrm{m}$ in thickness, (b) for thicker films, in most cases the wavelength range and/or wavelength resolution of the current hyperspectral imager did not appear to be sufficient (i.e. not high enough wavelength range or resolution, respectively) to obtain the desired thickness data, (c) the 
$\mathrm{x}$ (cross-web) resolution of the imaging data was dependent on the set field of view of the detector (6 inches) and the detector pixel density (2000 pixels), which in this case provided a 100 $\mu \mathrm{m}$ resolution, (d) the $\mathrm{y}$ (down-web) resolution of the imaging data was dependent on the webspeed $(1-4 \mathrm{ft} / \mathrm{min})$ and the camera frame rate $(100 \mathrm{~Hz})$, wherein the maximum y-resolution obtained was $50 \mu \mathrm{m}$, and (e) the estimated error in the thickness measurement was approximately $0.2 \mu \mathrm{m}$. [Q3-19]

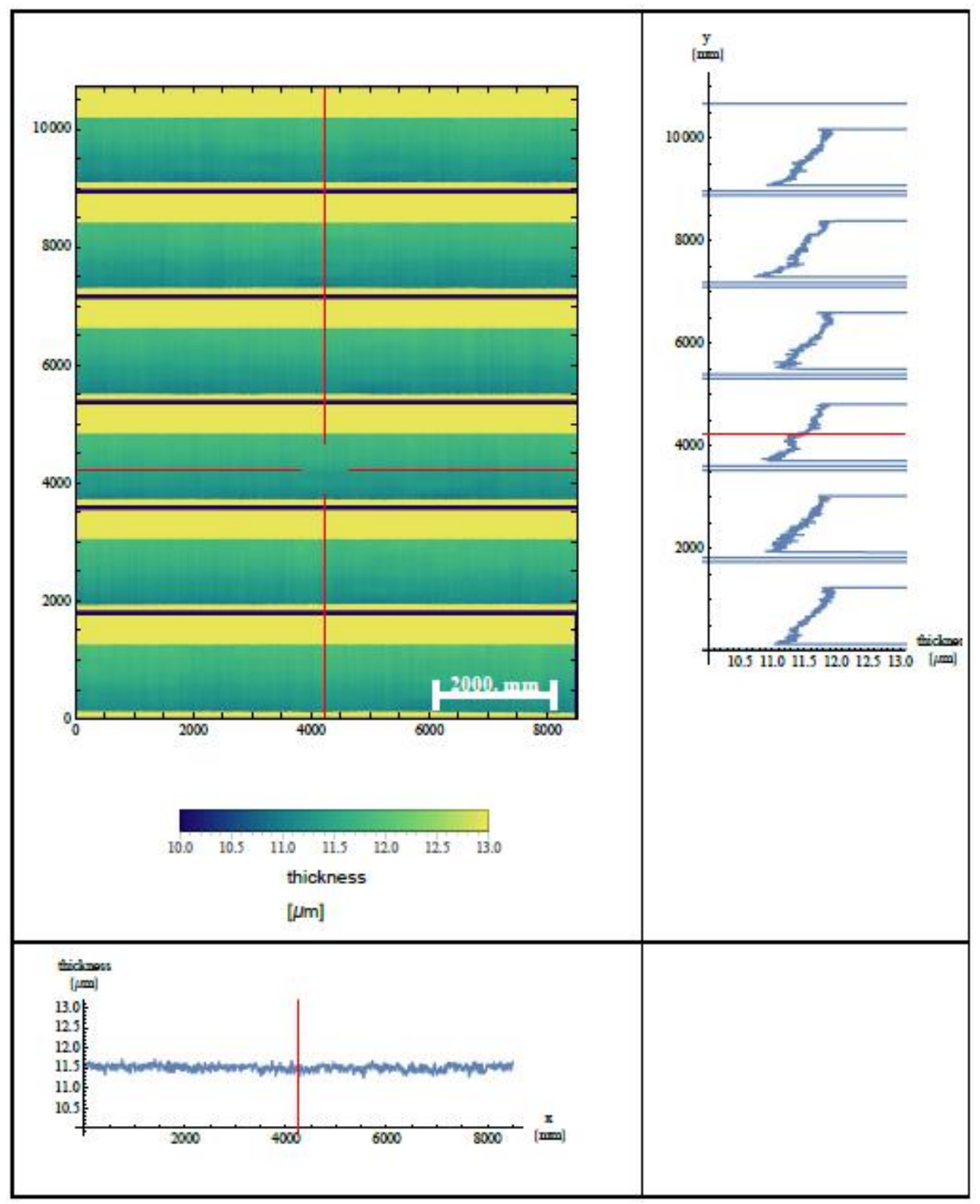

Figure 16. Thickness imaging maps of a fuel cell membrane from the second web-line demonstration. 
Further work on the hyperspectral imaging for membrane thickness mapping technique was then performed with a focus on thicker membranes of specific interest to low-temperature electrolysis (LTE) applications, because we had observed poor sensitivity to these membranes during our first web-line experiment. We used commercially available Nafion N115 (125 $\mu$ m thickness) as the example membrane for this study, in particular because the results of the first web-line experiment did not appear to show interference fringes being detected. Upon further manual analysis of the data (using improved peak detection), however, weak fringes were measured in the $800-1000 \mathrm{~nm}$ (near-IR) spectral range. This data was extracted and analyzed, as shown in Figure 17, which shows the thickness (x-axis) peak (the vertical yellow line) as a function of cross-web dimension (y-axis). This evaluation showed that the signal to noise ratio for thick membranes can be further improved, using a hyperspectral detector in the current wavelength range, by designing the detector with higher wavelength resolution. [Q1-20]

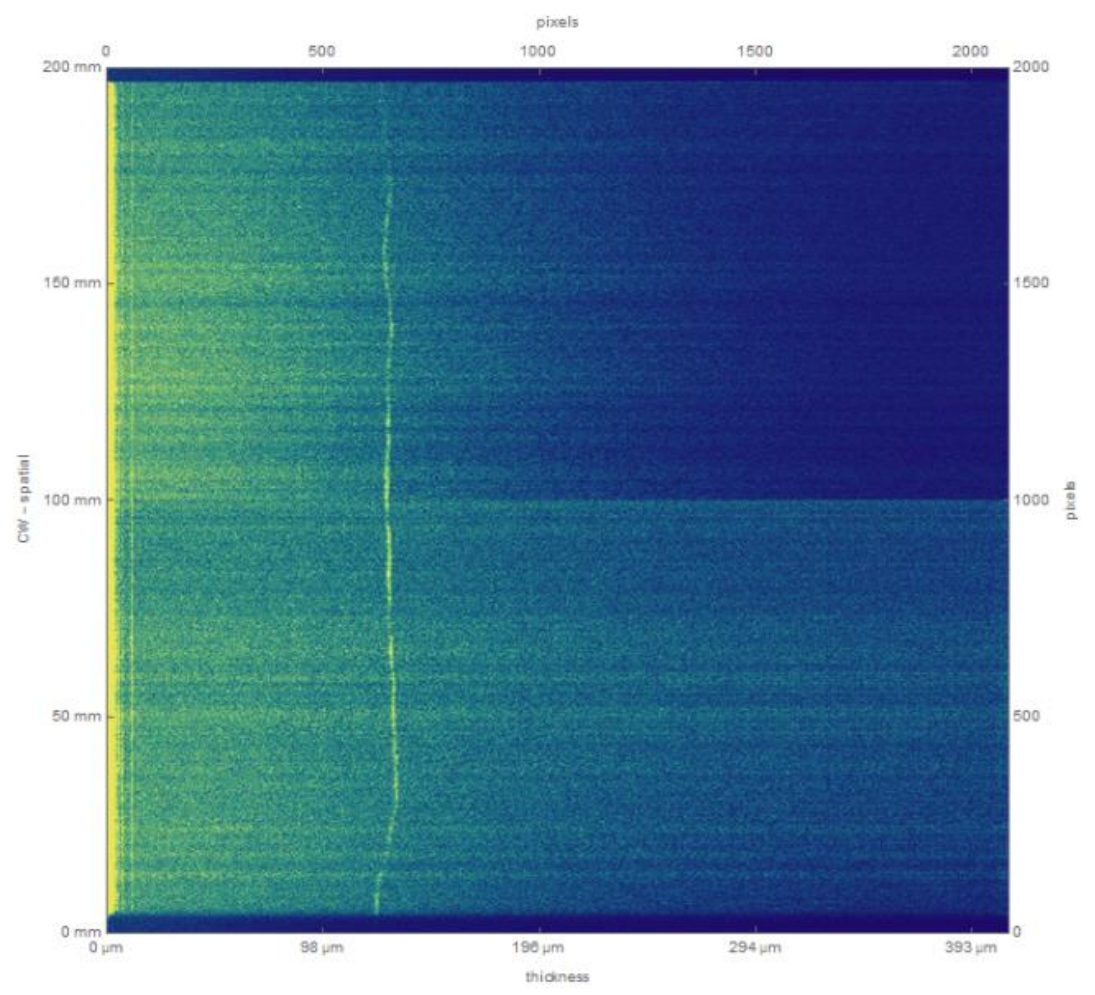
Figure 17. In-line hyperspectral imaging data, using improved peak detection, showing real-time cross-web thickness measurement of $\mathbf{N} 115$ (the bright yellow vertical trace represents the thickness (x-axis) as a function of cross-web position (y-axis)).

We also performed work to continue the development of the hyperspectral imaging technique for thin reinforced membranes. Nafion XL and HP reinforced membranes were used as representative cases. For the XL membrane, the thickness can easily be measured when measuring the membrane alone. Figure 18 shows the very strong interference fringe spectra that is able to be measured over a wide range of wavelength (left) and the peak detection using Fourier transform analysis (right). Interestingly, when measuring the entire 3-layer structure, we can get peaks for each individual layer, and it appears that the top protective sheet is the same thickness as the membrane. In a manufacturing implementation, it may be desired to change the thickness of the top sheet to enable better differentiation for the QC measurement. We also 
performed single-point near-infrared (NIR) spectroscopy for the XL membrane to understand if improved signal would be obtained. However, essentially the same results were obtained as with the silicon (UV-Vis) detector, i.e. no specific benefit of the slower, costlier NIR detector. [Q2-20]

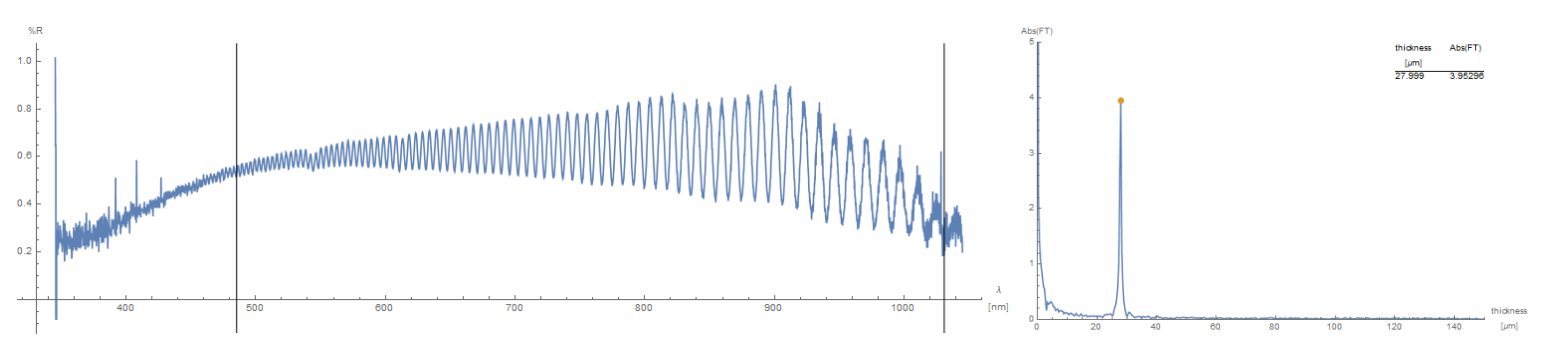

Figure 18. Single-point UV-Vis spectra (left) and Fourier transform peak (right) for Nafion XL membrane.

For the Nafion HP membrane, which has about the same structure as Nafion XL but somewhat different materials, we observed essentially the same results. The thickness of the membrane was easily measured with the UV-Vis detector. We also measured multiple cases of the membrane with one or both of the liners still attached, using both UV-Vis and NIR detectors. In these cases, the NIR detector provided higher signal to noise, but most cases were also measurable by UVVis. With the NIR detector, all three films can be measured simultaneously. [Q3-20]

Finally, we performed a third web-line experiment to understand the impact of line speed on yresolution (i.e. resolution in the down-web direction) of membrane thickness imaging, specifically at higher line speeds than were previously run. For the experiment, 6 runs were made at 3 different line speeds $(4,17,30 \mathrm{fpm})$. The hyperspectral camera acquired data at its maximum rate of $100 \mathrm{~Hz}$ for all runs. The 2000-pixel detector was set up with a cross-web field of view of 6.5 inches, resulting in a cross-web physical resolution of $0.08 \mathrm{~mm}$. The down-web resolutions were $0.2,0.86$, and $1.52 \mathrm{~mm}$ at the three line speeds, respectively. The runs were performed with a 25-meter-long roll of thin reinforced fuel cell membrane. Figure 19 shows an example of the data for sections of the web, taken at $30 \mathrm{fpm}$. In the image, the green colored area represents the film, with the thickness scale bar shown on the right. As noted above, at the constant frame rate, the line speed impacted the down-web resolution linearly. This effect can be seen graphically in Figure 20, where wrinkles in the membrane are seen in yellow in the top image, taken at $4 \mathrm{fpm}$. The bottom image shows the same section of membrane, where the data was taken at $30 \mathrm{fpm}$. Here, the wrinkles are barely visible because the down-web resolution is now on the order of the width of the wrinkles. An assessment was also performed of the repeatability of the measurement under different line speed conditions. The thickness at a specific location on the web, identified by an easily observed defect, was compared at the three line speeds. Very good agreement of the measured thickness was found. [Q3-20] 


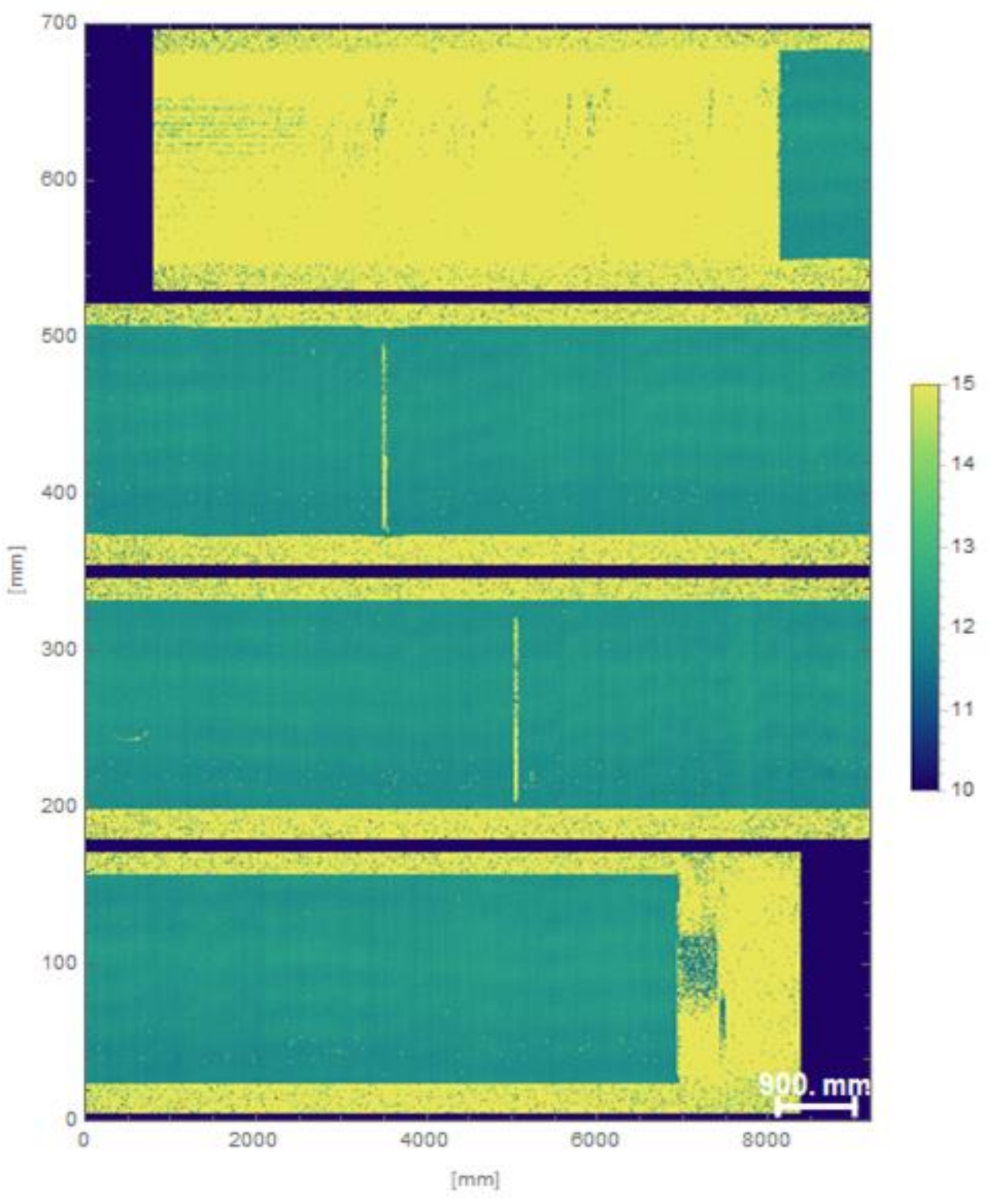

Figure 19. Representative thickness imaging results at $30 \mathrm{fpm}$ (units of scale bar are $\mu \mathrm{m}$ ). 


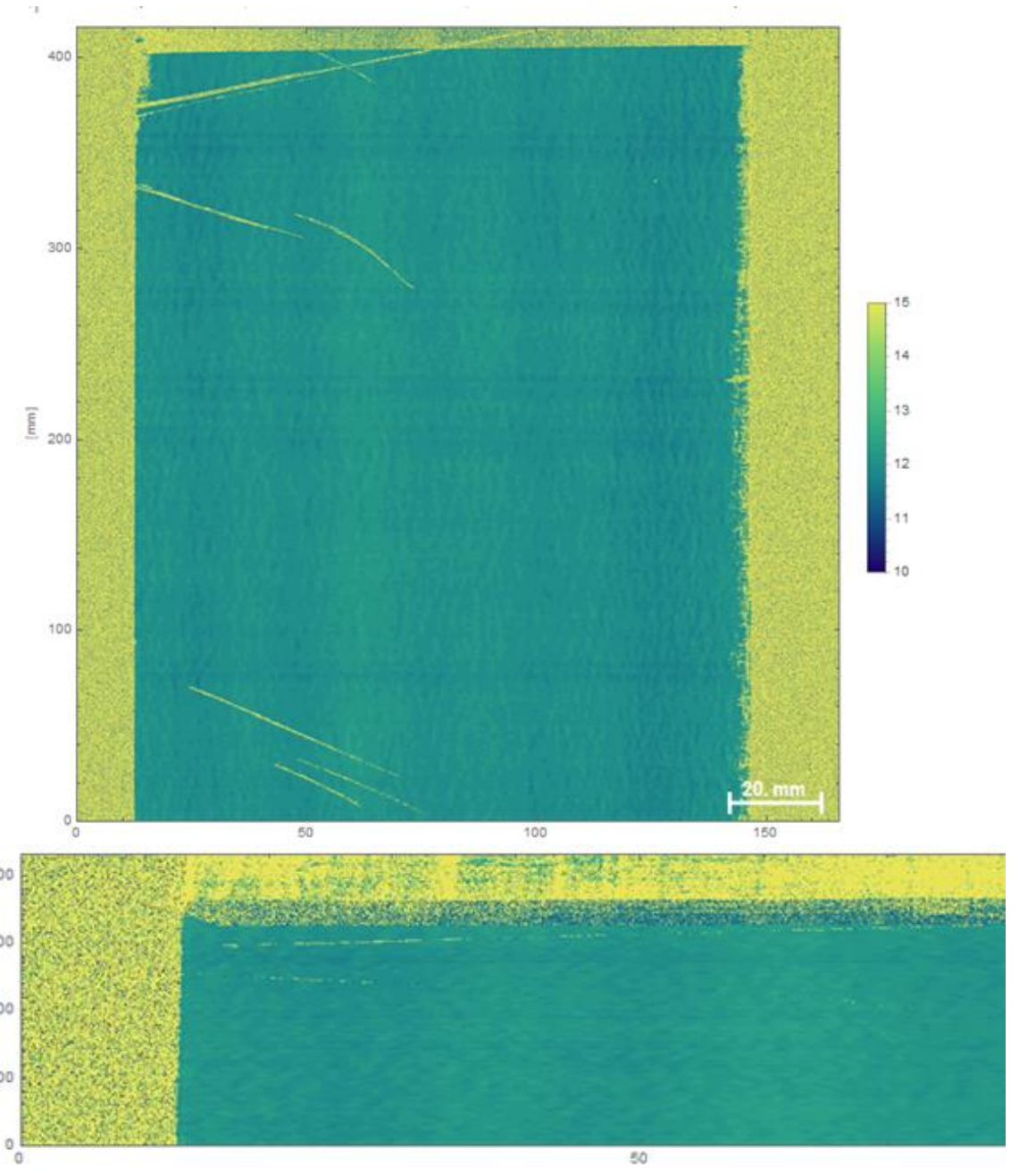

Figure 20. Change in down-web resolution represented by the change in imaging of wrinkles between $4 \mathrm{fpm}$ line speed (top) and $30 \mathrm{fpm}$ (bottom) (units of scale bar are $\mu \mathrm{m}$ ).

In summary for Task 1, we completed web-line experiments using multiple membranes of different structure and thickness to demonstrate an in-line capability to perform thickness mapping via the hyperspectral imaging technique and to assess the impact of measurement conditions such as line speed on signal-to-noise ratio and measurement resolution. We improved our data processing algorithms to be faster and to operate on a larger set of the imaging data. We performed comparisons between UV-Vis and NIR detectors to understand the impact of spectral range, trading off speed and cost against improved sensitivity. And we performed additional studies to further understand the operation of the technique with respect to thick membranes for LTE as well as thin reinforced membranes for fuel cells.

\section{TASK 2: Fabricate Reference Samples}

As necessary, NREL will create, by simulated or as-fabricated methods, relevant samples with representative defects to assist in its and Mainstream's development activities. NREL will provide samples to Mainstream for blind testing along with data on the type, size, and location of defects from a reference technique (e.g., 3D optical microscopy). 


\section{Results for Task 2:}

The key study intended for Task 3 was to understand the impact of membrane pinholes, and in particular to understand how the thickness and/or presence of a reinforcing layer or material would mitigate the impact of a pinhole. As such, our main activity under Task 2 was the creation of a set of membrane samples with highly precise pinhole diameter. As such, we interacted with a laser machining supplier to fabricate this sample set. A set of protocols for laser drilling of the precision holes in Nafion membranes was established, and we prepared and provided to the supplier a set of membrane samples (of two thicknesses and with and without reinforcement) for laser drilling. The samples included four different pinhole diameters, from 10-100 $\mu \mathrm{m}$, using three different membranes (Nafion 211, 212 and XL), with several replicates of each sample. Optical microscopy was performed by the supplier to verify the desired diameters. [Q4-18 - Q219]

In addition to the pinhole study, Mainstream was interested to test their system for the optical imaging of electrode loading technique that we have previously demonstrated. To support their effort, we performed $\mathrm{x}$-ray fluorescence (XRF) mapping of several catalyst-coated membranes (CCM) and gas-diffusion electrodes (GDE), both across a range of catalyst loading, so that they could attempt to spatially compare their optical imaging data to direct elemental measurement (which we had not previously done). Several improvements were made to the XRF mapping procedure to improve operability and reduce error. Figure 21 shows a representative XRF map for one of the CCMs, which was at a point-to-point $\mathrm{x}-\mathrm{y}$ resolution of $1.82 \mathrm{~mm}$. The estimated total spatial variation in loading was 3.5\%. All of the mapped CCMs and GDEs, with the spatial XRF data, were sent to Mainstream for measurement and analysis using their optical system.

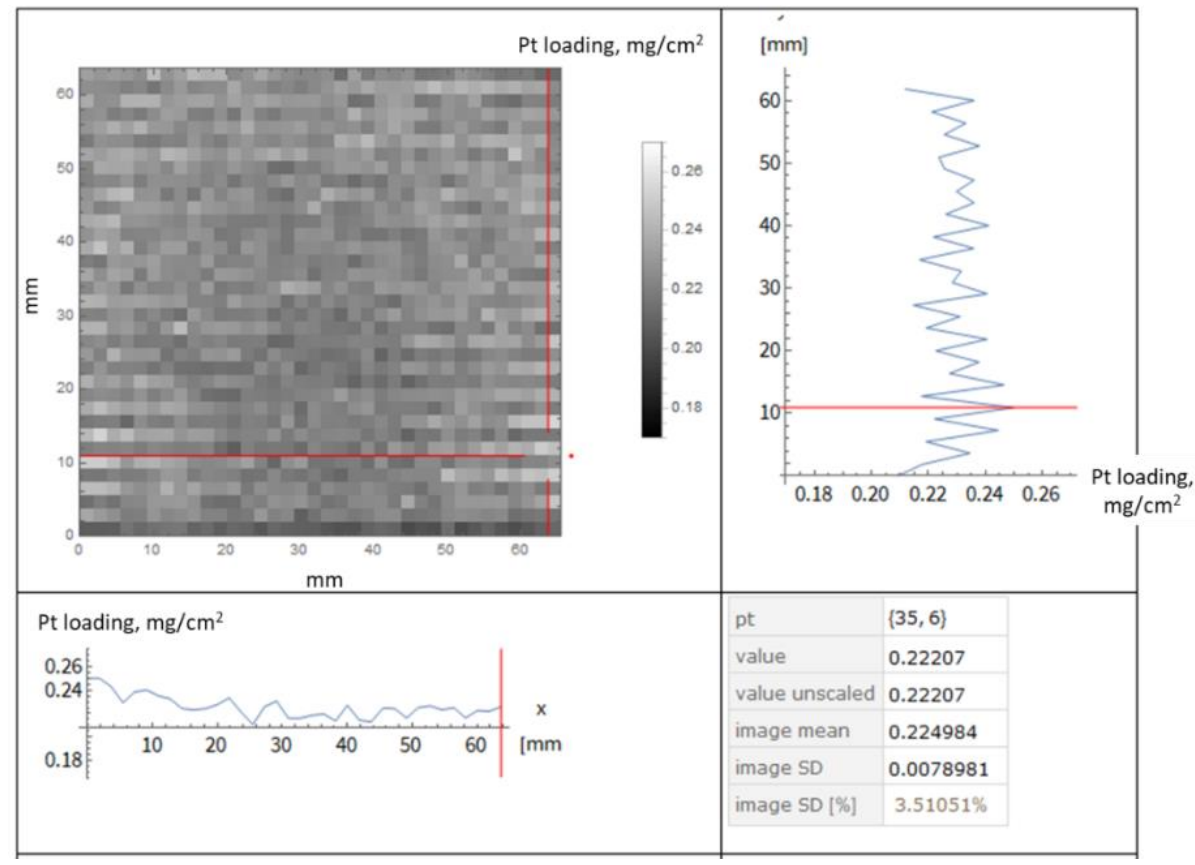

Figure 21. XRF mapping of CCM with nominal loading of $0.2 \mathrm{mg} \mathrm{Pt/cm2.}$ 


\section{TASK 3: Study the impact of inhomogeneities in MEA materials}

NREL will perform studies using a segmented cell test station to determine the effect of MEA material defect type and size on fuel cell performance in order to elucidate minimum defect size/type that leads to decrease in performance over time or earlier cell failure (compared to a pristine cell). These criteria will be used to help determine the necessary limits of detection for Mainstream's prototype measurement system.

\section{Results for Task 3:}

As noted above, the initially intended focus of Task 3 for NREL was a study of the impact of membrane pinholes. This study would expand upon the prior studies using as-cast membranes with defects fabricated at GT and mechanically punched membranes fabricated at NREL in two key ways: (1) we would look at smaller pinholes, from 10-100 $\mu$ m diameter, and (2) we would look at reinforced in addition to unreinforced membranes. A critical aspect of this study was to understand how the cell assembly process would further affect the pinhole. We wanted to understand what happens to the electrode material if it is deposited over a pinhole or hot pressed adjacent to one, if the electrode material flows into the pinhole, and if so, how does this impact the effect of the pinhole.

To support this study, we set up an experimental testbed and explored the behavior of membrane materials with pinholes under different conditions of relative humidity and temperature. The motivation was to understand, given the extreme hygroscopic nature of PFSA membranes, what happens to a pinhole while operating in a cell under different RH and temperature conditions. For this study, a microscopy system was set up in an environmental chamber, as shown in Figure 22. Here, a small remote microscopy head is sealed in a chamber to protect the electronics from the humidity in the chamber, and a membrane sample is affixed (in these initial experiments, only with tape) on a 3-axis stage. The stage is not remotely controlled, so the sample is brought into focus of the microscope first, then the chamber is closed and brought to the experimental condition. At low humidification, the scheme worked well to observe and measure the pinhole diameter (see imaging in Figure 23). However, at higher humidity, the membrane began to deform (i.e., underwent non-uniform swelling in the $\mathrm{x}, \mathrm{y}$, and/or $\mathrm{z}$ dimensions) to an extent that the pinhole moved out of the focal point of the microscope, thus calling into question quantitative measurement of the pinhole shape or diameter. In a very nicely coordinated modeling effort, LBNL modeled the strain on a similarly sized $(250 \mu \mathrm{m})$ pinhole resulting from humidity at $80^{\circ} \mathrm{C}$. They also calculated the strain on the pinhole from several of our experimental data points, given the measured change in pinhole size. Figure 24 shows that the first several experimental measurements qualitatively match to the model trend. However, at higher humidity, as previously noted, the poor diameter measurements cause a divergence. In future efforts, we will refine the experimental setup for this work, including methods to constrain the movement of the membrane and/or using a remotely controlled 6-axis stage to be able to bring the pinhole back into the focal plane of the microscope after the membrane deformation, in the higher humidity cases. [Q2-19-Q2-20] 

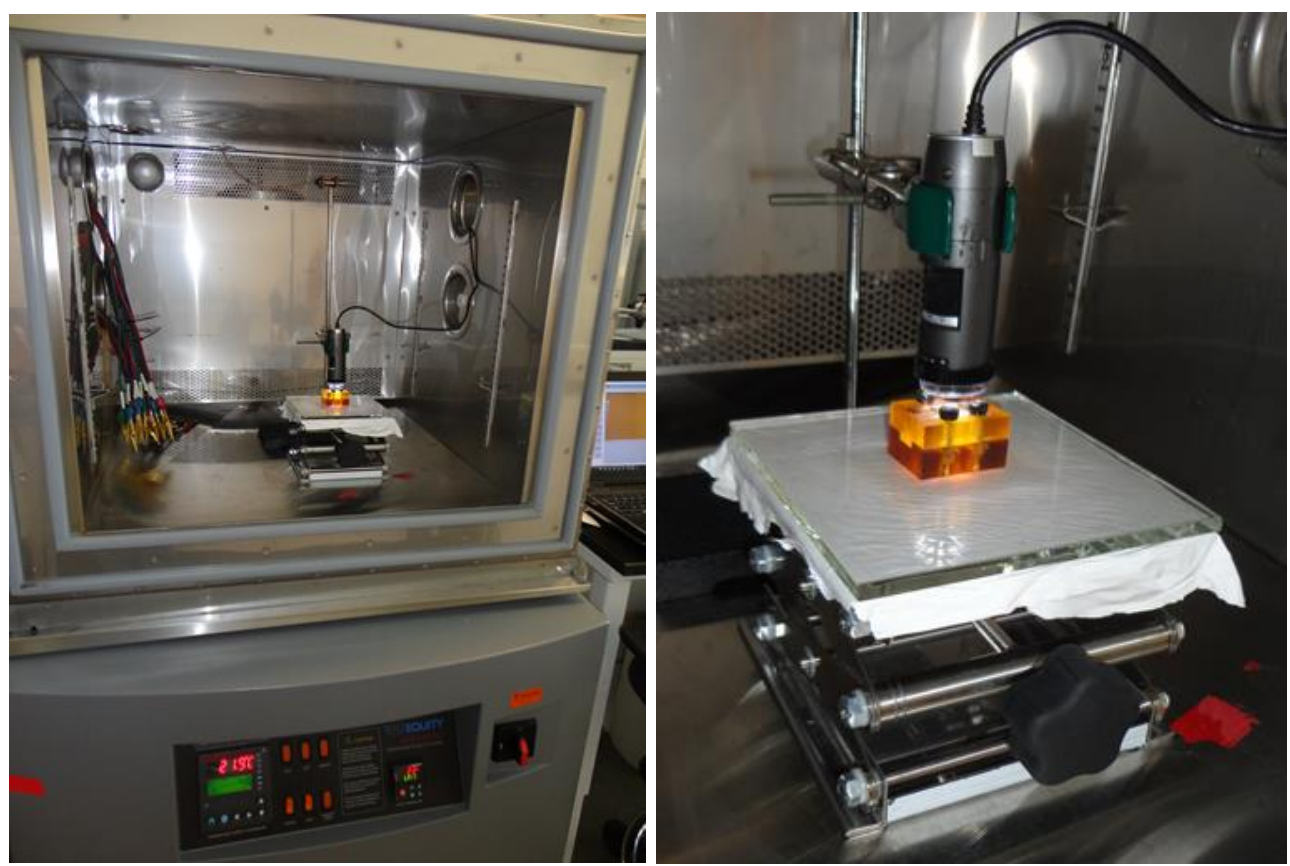

Figure 22. Environmental chamber with USB microscope and membrane sample holder (left), close-up of USB microscope, holder and translation stage (right).

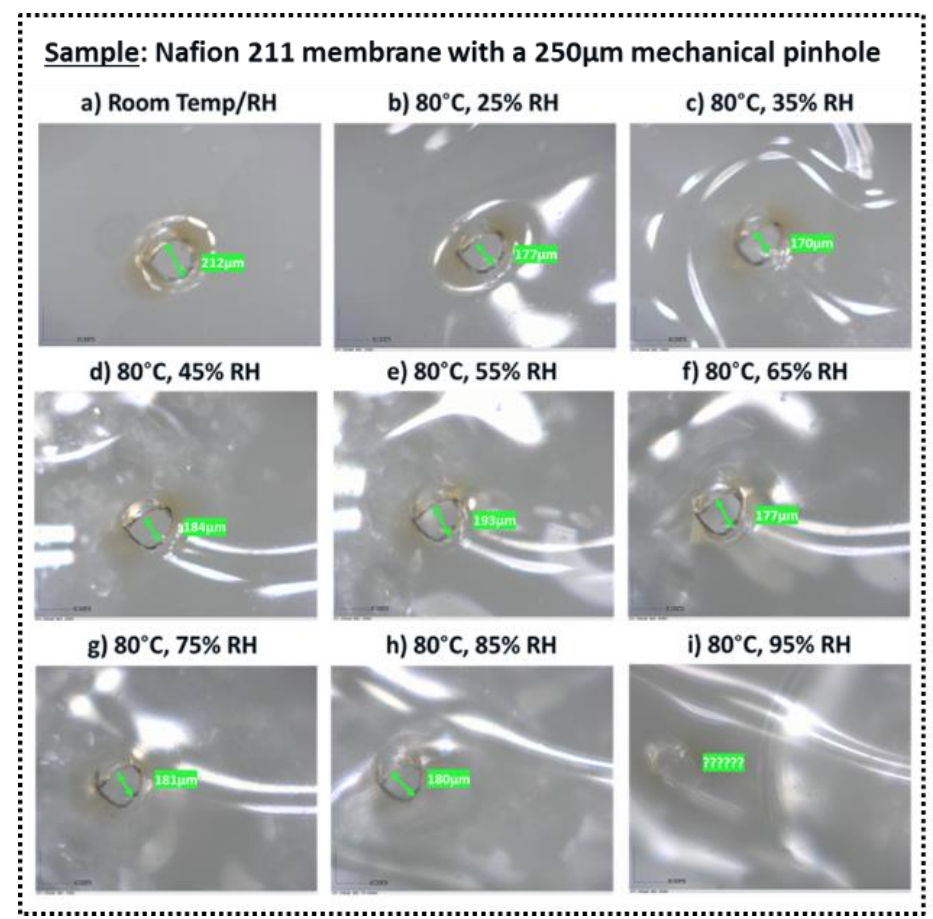

Figure 23. Pinhole imaging results under room and high temperature and different humidity conditions. 


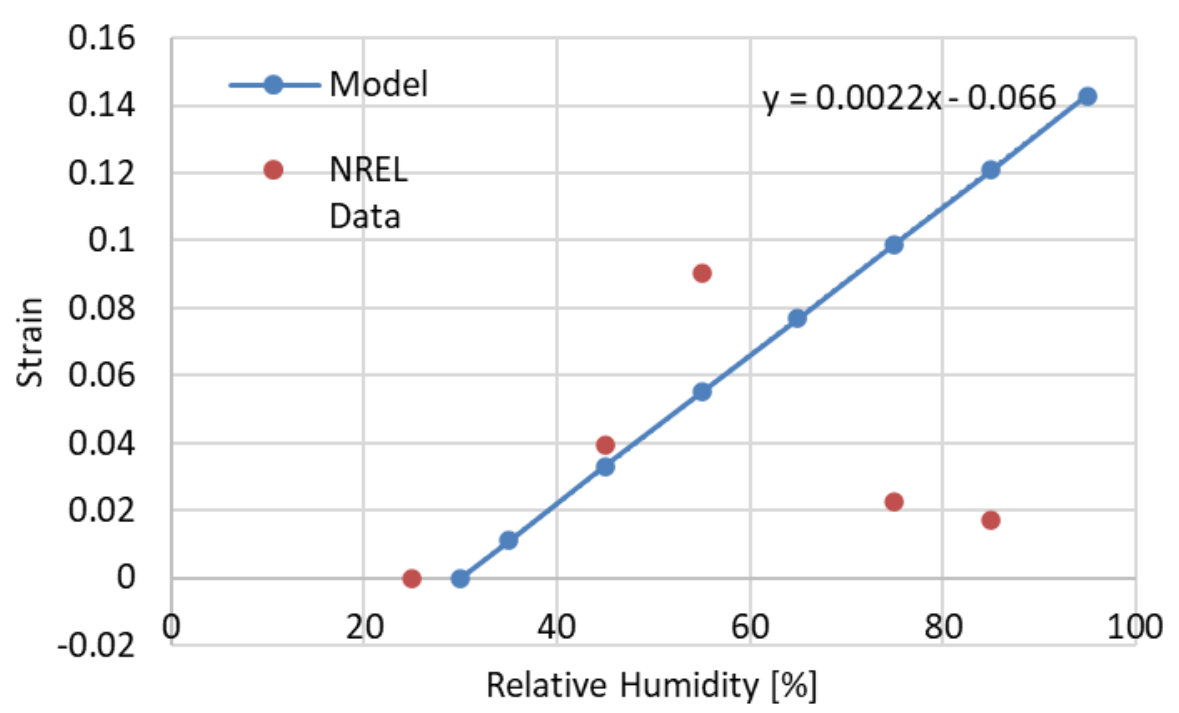

Figure 24. Pinhole strain as a function of humidity at $80^{\circ} \mathrm{C}$ : LBNL mechanical model and NREL microscopy data.

We then fabricated a CCM using a Nafion 211 (25 $\mu \mathrm{m}$ thick) membrane with a $100 \mu \mathrm{m}$ laserdrilled pinhole in the center of the cell. $\mathrm{H} 2 \mathrm{XO}$ was measured before break-in and after break-in at $25^{\circ} \mathrm{C}$ and $80^{\circ} \mathrm{C}$. The values were within normal ranges, though some apparent shorting was observed. The crossover could be increased by providing an overpressure on the anode, but still not to unusual levels. Ex situ testing of the same MEA (after break-in but prior to any in situ testing) using our pinhole detection apparatus (PDA), which flows hydrogen past one side of the cell and images any heat generation on the opposite side electrode using thermography, also showed very minimal crossover. This result was somewhat surprising, as we expected a $100 \mu \mathrm{m}$ pinhole to have a greater initial impact. Thus, with respect to our questions of how the cell assembly process might impact the pinhole, we questioned if the electrode material that was directly sprayed onto the membrane (including the pinhole) actually "capped" the pinhole with electrode ink? And did the ink wick or weep down into the pinhole, potentially blocking the gas transport pathway? And we also questioned if a GDE-style MEA, where the electrode ink would not be in contact with the membrane pinhole as a liquid, have a different result? And what would be the effect of hot-pressing? [Q3-19]

Continuing in this regard, we fabricated a cell using an identical membrane (with a $100 \mu \mathrm{m}$ pinhole) paired with GDEs (instead of directly coating the electrode material onto the membrane) to make an MEA. In this case, the electrodes would not be integral to the membrane, rather adjacent. For this MEA, the pinhole was clearly observed in the ex situ PDA testing, and very poor open circuit voltage (OCV) was measured in situ, confirming the impact of the pinhole. This being the case, we initially set out to pursue our exploration of pinholes using GDE-based MEAs, so that the CCM fabrication effects, for the moment, would not confound the effects of the pinholes. In doing so, and in performing detailed ex situ and in situ characterization of what were intended to be pristine GDE-based MEAs, i.e. MEAs with intact membranes and no other known defects, we found that ALL pristine MEAs, using Nafion 211 membrane with no pinholes, had "warm spots" (indicating a low but measurable amount of crossover) as indicated by our ex situ and quasi-in situ spatial infrared techniques. This was problematic because these 
warm spots confounded evaluation of the impact of pinholes. In order to support fabrication of pristine MEAs for the intended pinhole study, we therefore explored the origin of these warm spots. We explored the impact of hot-pressing parameters, GDL type/microporous layer (MPL) roughness, application of an ionomer overlayer to the GDE surface, and membrane type and thickness. We found that (a) GDL with less rough MPL leads to less/less extreme warm spots (see Figure 25), (b) hot-pressing temperature and pressure, for each membrane, can be optimized to minimize the formation of warm spots, though at the expense of initial performance (see Figure 26), (c) thicker and reinforced membranes have less warm spots, but not zero (under unoptimized hot pressing conditions), (d) the application of an ionomer overlayer onto the cathode electrode drastically improves the performance of GDE-based MEAs (as previously determined), but does not reduce the formation of warm spots (see Figure 27), (e) as determined by scanning electron microscopy (SEM) cross-sections of the MEA at the location of the warm spot, the warm spots are in fact thin spots and in some cases small fissures in the membrane caused in most cases by either pinching/puncturing by GDL fibers or by formation of compression points at MPL cracks (see Figure 28), (f) as determined by using accelerated stress testing in concert with the spatial infrared diagnostics, the pre-operation warm spots actually form seed-points for failure (see Figure 29), and (g) we also observe this effect in hot-pressed CCMs (while CCMs don't always need to be hot-pressed, this proves that this pre-operation failure point formation can happen via either CCM-based or GDE-based MEA fabrication processes). This work potentially indicates that many if not most MEAs contain seed points for failure that result from the MEA fabrication process. In essence, the cells that we all consider to be pristine really aren't - we just can't tell this without NREL's ex situ and quasi-in situ infrared diagnostics. With the materials and processing conditions optimized to greatly minimize the formation of preoperation warm spots, we next moved forward with studies of membranes with known pinholes. [Q4-19 - Q1-20] 
$\mathrm{H} 23 \mathrm{C} 8,1600 \mathrm{~kg}, 0.023 \mathrm{mg}$ Nafion $/ \mathrm{cm}^{2}$

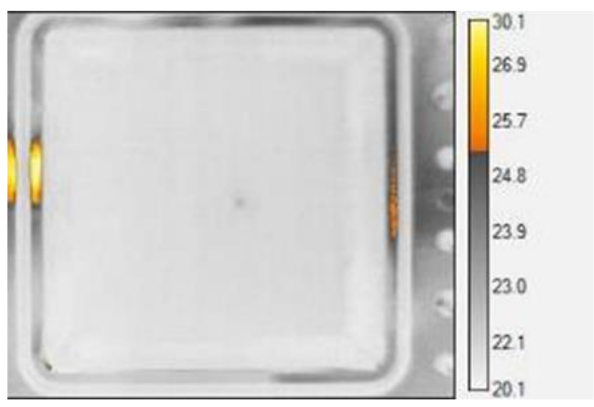

$29 B C, 1600 \mathrm{~kg}, 0.023 \mathrm{mg}$ Nafion $/ \mathrm{cm}^{2}$

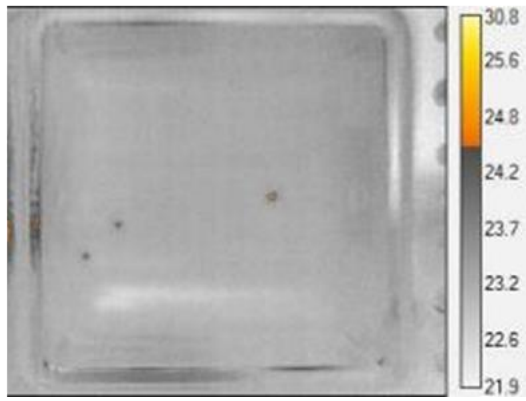

H23C8, 1600kg, no IL

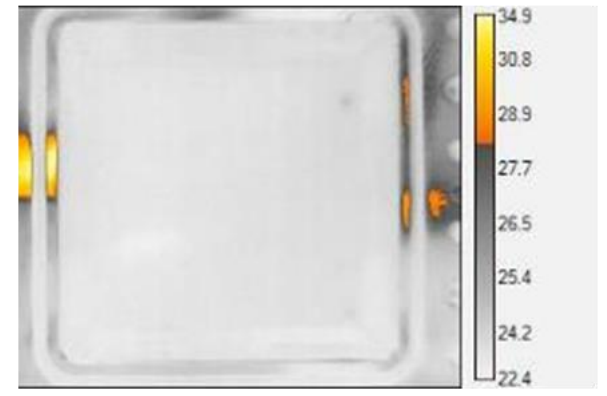

$29 B C, 1600 \mathrm{~kg}$, No IL

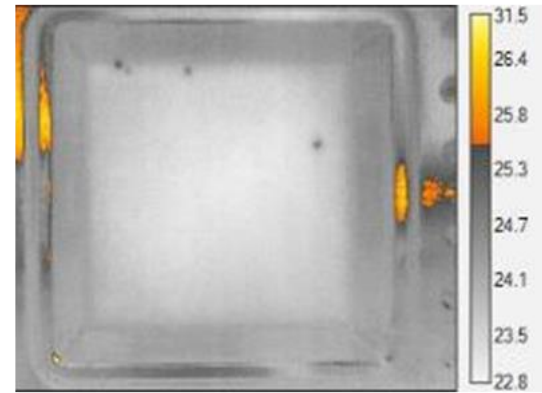

Figure 25. Impact of GDL type/MPL roughness on formation of warm spots (H23C8 has a much smoother MPL than 29BC), MEAs on the left have an ionomer overlayer, MEAs on the right do not (temperature scale in ${ }^{\circ} \mathrm{C}$, total MEA area was $50 \mathrm{~cm}^{2}$ ).

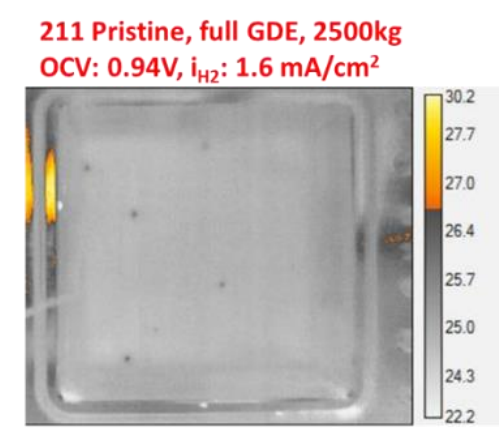

211 Pristine, full GDE, $800 \mathrm{~kg} / \mathrm{OCV}$ : $0.961 \mathrm{~V}$

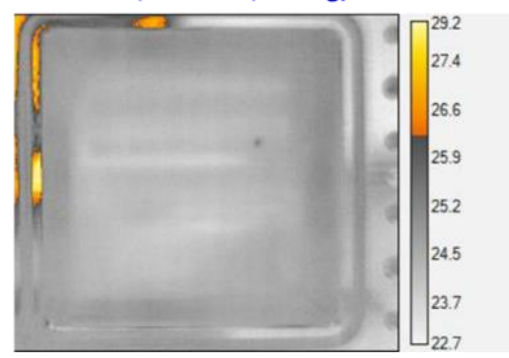

211 Pristine, full GDE, 1600kg

OCV: $0.96 \mathrm{~V}, \mathrm{i}_{\mathrm{H} 2}: 1.22 \mathrm{~mA} / \mathrm{cm}^{2}$

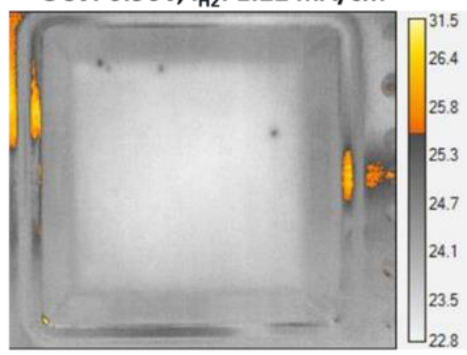

211 Pristine, SGL 29BC, edge protection, no IL

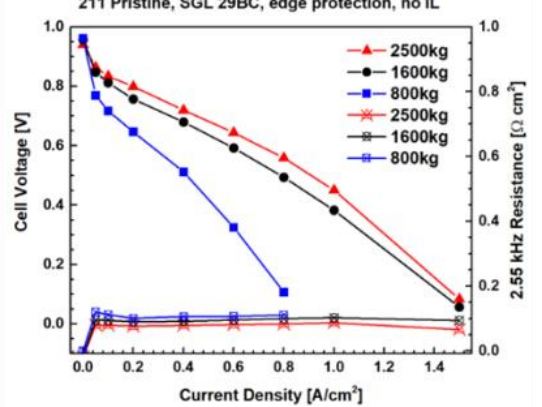

Figure 26. Impact of hot-pressing pressure on warm-spot formation and performance (temperature scale in ${ }^{\circ} \mathrm{C}$, total MEA area was $50 \mathrm{~cm}^{2}$ ). 
29BC, $1600 \mathrm{~kg}$, No IL: OCV: $0.96 \mathrm{~V}, \mathrm{i}_{\mathrm{H} 2}: 1.22 \mathrm{~mA} / \mathrm{cm}^{2}$

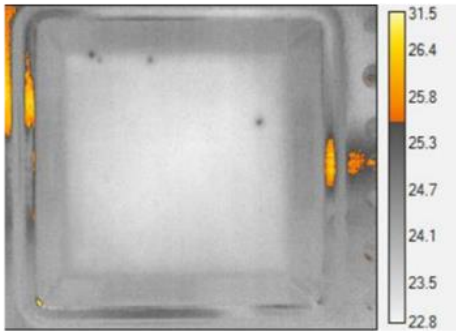

29BC, $1600 \mathrm{~kg}, 0.023 \mathrm{mg}$ Nafion $/ \mathrm{cm}^{2}$ on cathode OCV: $0.96 \mathrm{~V}, \mathrm{i}_{\mathrm{H} 2}: 1.2 \mathrm{~mA} / \mathrm{cm}^{2}$

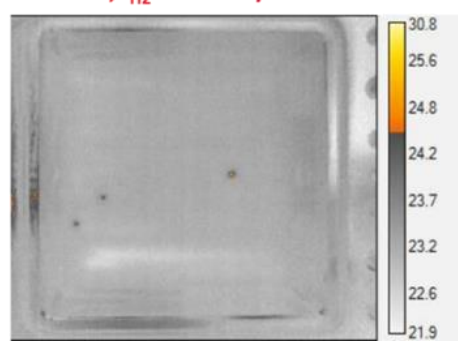

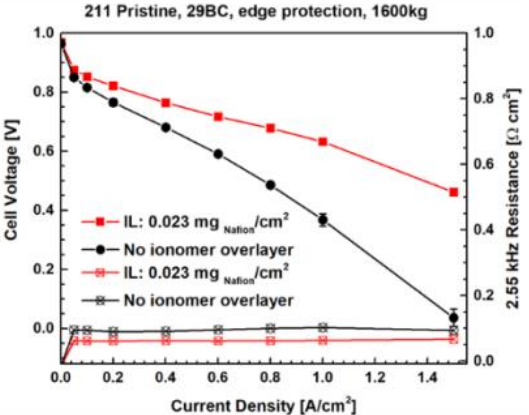

Current Density $\left[\mathrm{A} / \mathrm{cm}^{2}\right]$

Figure 27. Impact of application of an ionomer overlayer on formation of warm spots and performance (temperature scale in ${ }^{\circ} \mathrm{C}$, total MEA area was $50 \mathrm{~cm}^{2}$ ).

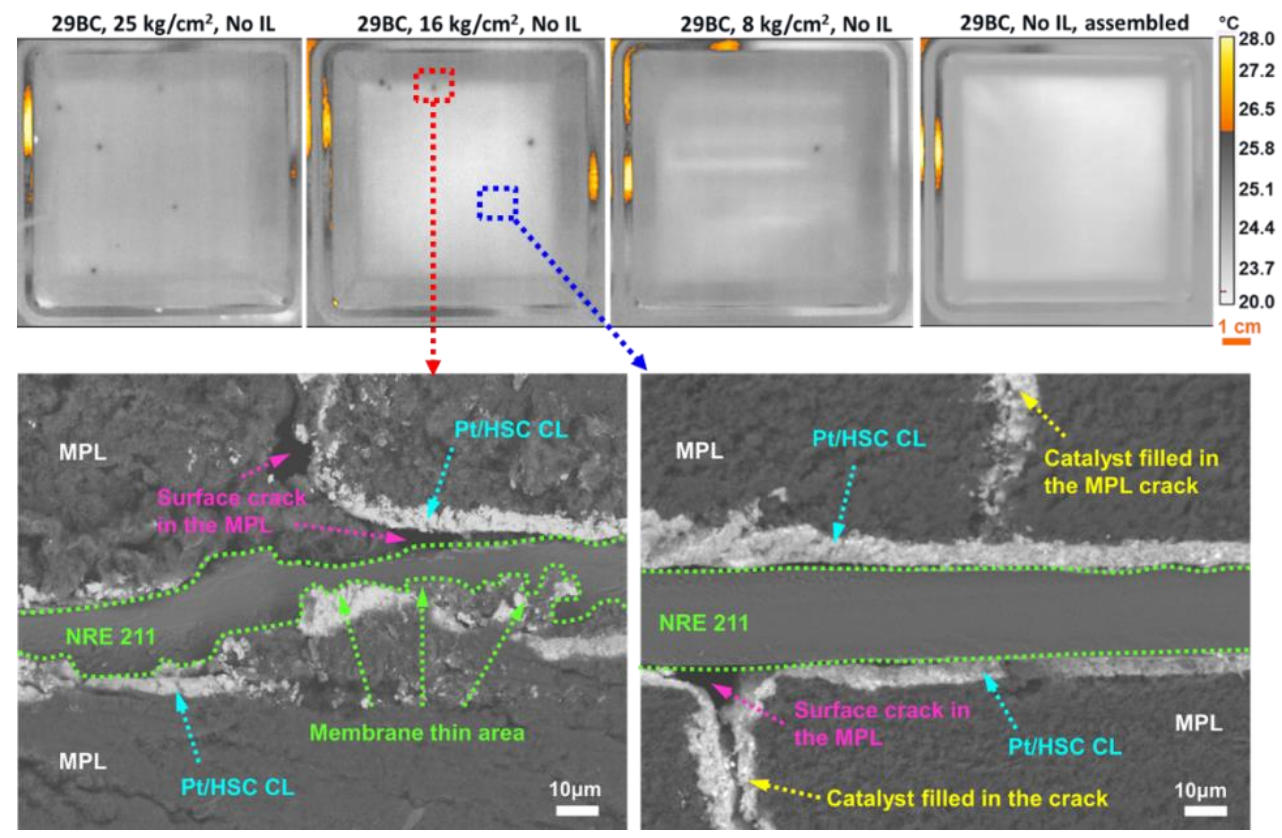

Figure 28. Quasi-in situ IR imaging (top) and SEM cross-sections (bottom) of pristine GDE-based

MEAs at the location (left) of a warm spot (indicated by red dotted box and line), showing membrane thinning and deformation, and (right) where there is no warm spot (indicated by blue dotted box and line), showing an unaffected membrane. 


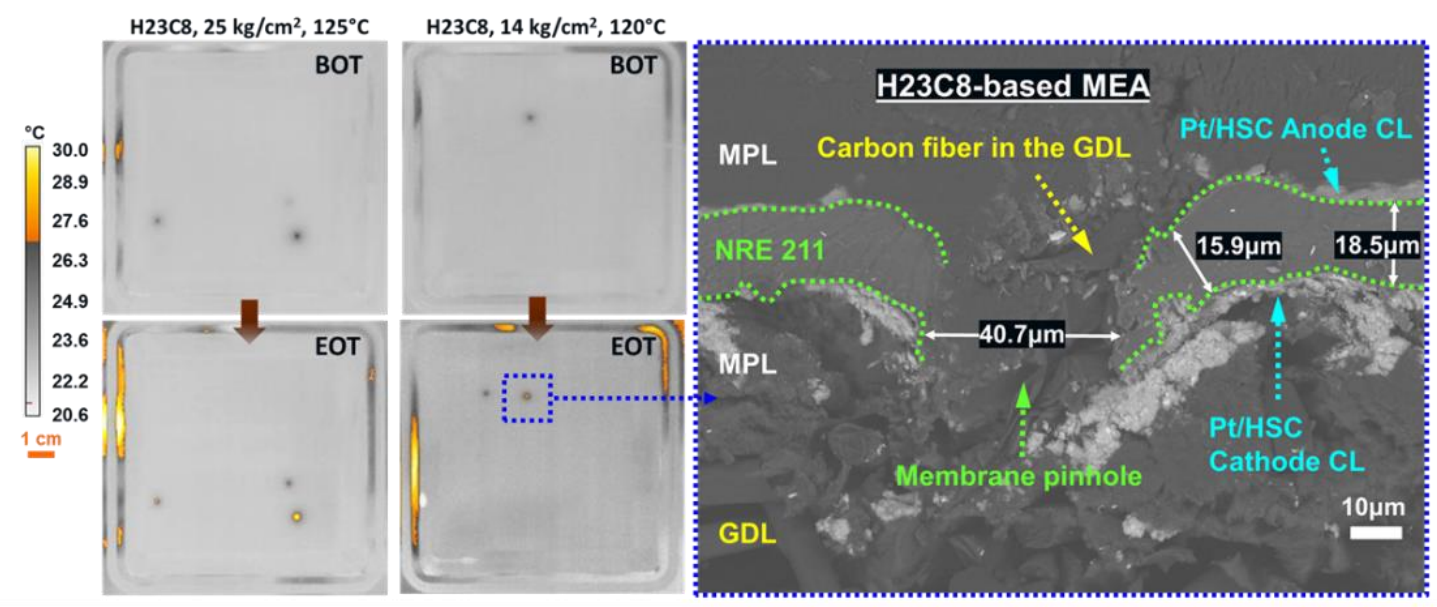

Figure 29. Quasi-in situ IR imaging of pristine GDE-based MEAs (left) before AST (top) and after AST (bottom) showing that the warm spot resulted in a failure point; and SEM cross-section (right) of the indicated failure point (blue dotted box and line) showing the fissure in the membrane.

Using Nafion 212 (50 $\mu \mathrm{m}$ thick) membranes with laser-drilled holes of precise diameter (from 10 to $100 \mu \mathrm{m}$ ) and GDEs to fabricate cells (using the optimized hot-pressing conditions identified above), we performed studies including the initial (before test) quasi-in-situ crossover of hydrogen using our IR method; in situ air polarization, $\mathrm{OCV}$, and $\mathrm{H} 2 \mathrm{XO}$; and time to failure using a combined chemical-mechanical accelerated stress test (AST). Figure 30 shows the pretest crossover behavior of a series of cells with membrane pinholes of 100, 50, 20, and $10 \mu \mathrm{m}$ diameter. These MEAs were hot-pressed but had not been humidified or operated in any way. It is clear that, even with the pinhole, the diffusion of hydrogen in the dry state is only apparent with the largest pinhole. Figure 31 shows the air polarization, OCV, and $\mathrm{H} 2 \mathrm{XO}$ for these cells upon test. These initial performance results provide essentially the same result: we only see impact of the largest pinhole. Figure 32 shows the AST results, where we see a drastically shorter lifetime of the MEA with the $100 \mu \mathrm{m}$ pinhole, but surprisingly, we see little if any impact of the MEA with the $50 \mu \mathrm{m}$ pinhole. Interestingly, in the quasi-in-situ IR imaging of the MEA with the $100 \mu \mathrm{m}$ pinhole before testing and after the AST, we can see that the pinhole was actually not the main failure point of the MEA - a larger failure point developed at a different location. For cells fabricated with the thinner Nafion XL membrane ( $25 \mu \mathrm{m}$, reinforced), Figure 33 shows that we can see evidence of hydrogen crossover before test for the three larger pinholes, but not the smallest. Note that the hole is through the reinforcement, so there is no benefit of the reinforcement in this case. Clearly, in the dry state, hydrogen can diffuse through the pinhole more easily when the membrane is half as thick. The in situ performance results for the Nafion XL-based MEAs, however, were the same as those for Nafion 212: air polarization only showed an impact of the largest pinhole. And in AST testing, the MEA with the largest pinhole again failed very quickly. Note that in AST testing of pristine MEAs with these two membranes, the MEA with the reinforced membrane, even at half the thickness, lasted at least five times longer. This is qualitatively as would be expected, and shows that, if handling and processing of an MEA with a reinforced membrane should cause a pinhole or fissure in the membrane, the reinforcement may not be of great value to extend the lifetime of the MEA. [Q2-20] 
IR thermography of NRE 212 MEAs after hot-pressing, before any test (BOT)
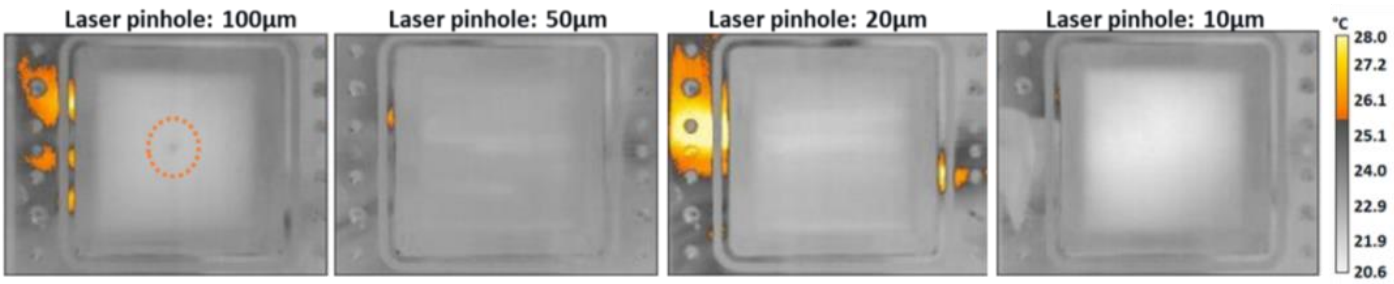

Figure 30. Quasi-in-situ hydrogen crossover of MEAs with pinholes in Nafion 212 membranes using NREL's unique IR hardware.
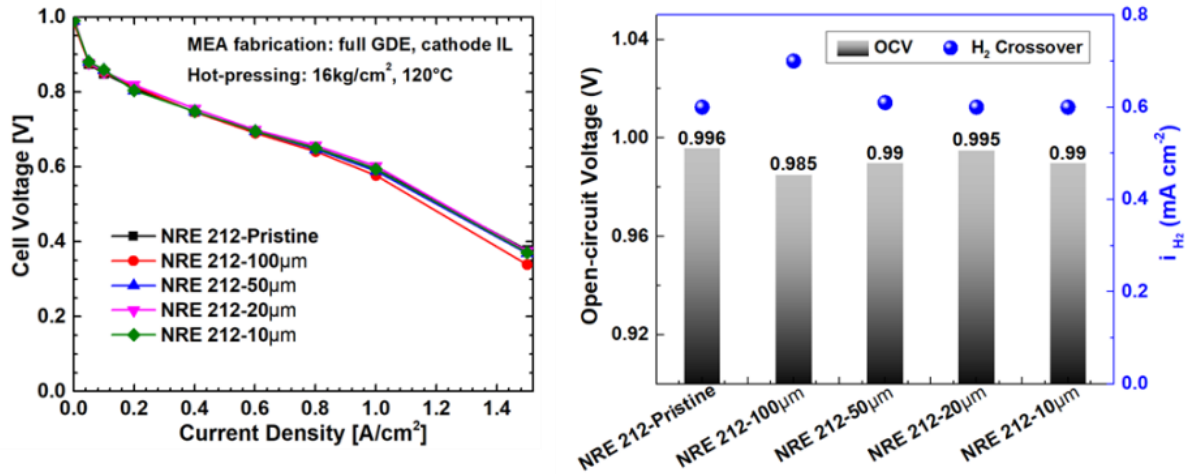

Figure 31. Air polarization (left), OCV and H2XO (right) for MEAs with pinholes in Nafion 212 membranes.

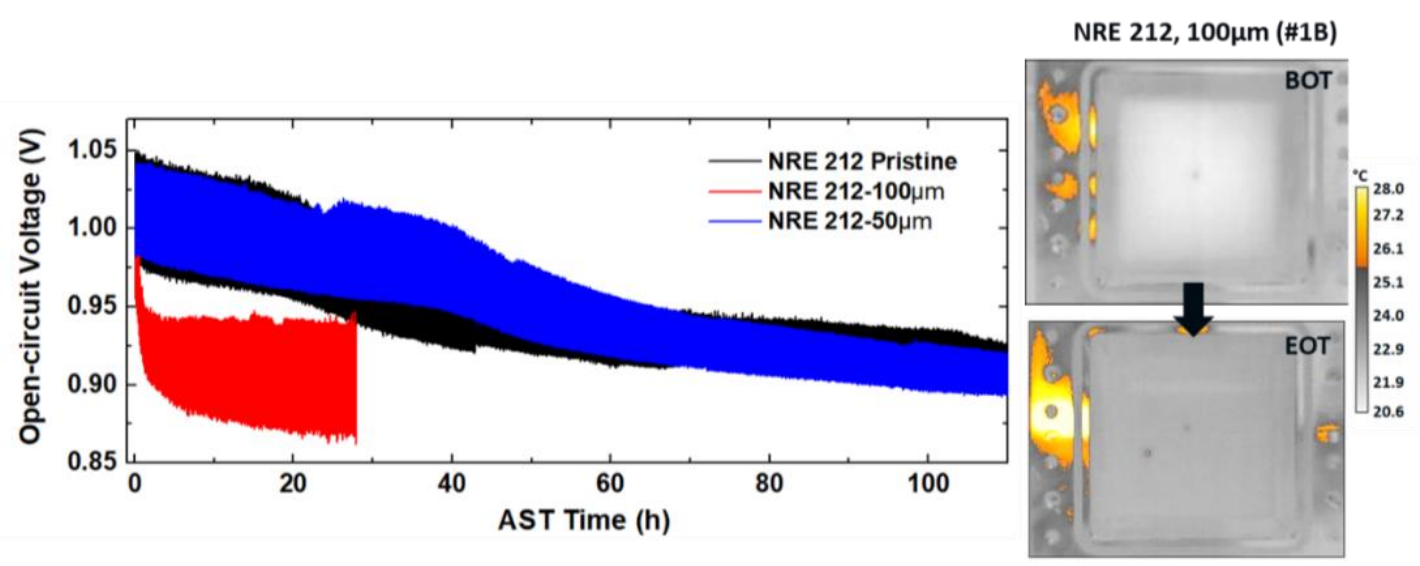

Figure 32. OCV as a function of AST time (left) for three Nafion 212-based MEAs, and comparison of quasi-in-situ hydrogen crossover before and after AST for the MEA with a $100 \mu \mathrm{m}$ pinhole.

IR thermography of Nafion XL MEAs after hot-pressing, before any test (BOT)
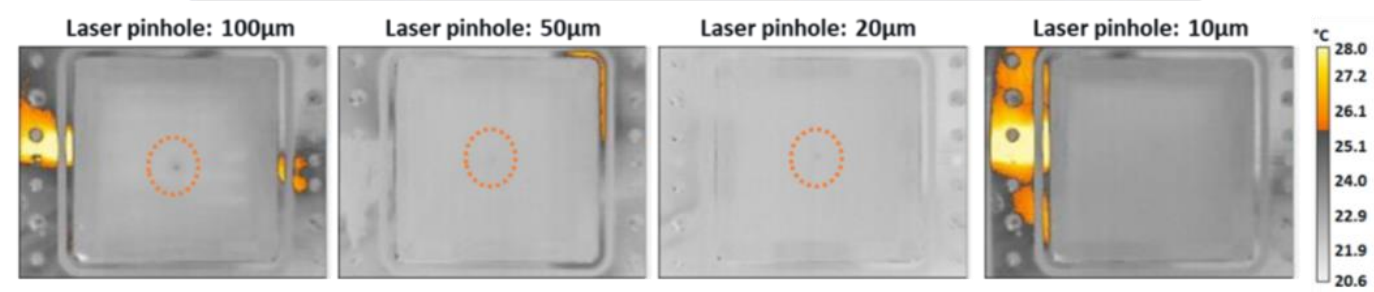

Figure 33. Quasi-in-situ hydrogen crossover of MEAs with pinholes in Nafion XL membranes using NREL's unique IR hardware. 
In continuation of the work on Nafion XL-based MEAs we found that, while slight modification of hot-pressing conditions typically eliminated the warm spots in the thicker Nafion 212 membrane, the thinner XL membrane was quite similar to Nafion 211, even with the reinforcement, where some level of crossover was observed under most hot-pressing conditions. Also similar to the Nafion 211 results, for Nafion XL-based MEAs where warm spots were observed before test, these locations became failure points in the AST test. Thus, as mentioned above for the case of intentionally created pinholes, while extending the AST lifetime of an MEA when no before-test crossover is seen, the reinforcement in the Nafion XL membrane actually does not appear to improve the lifetime of the MEA when a failure point resulting from MEA fabrication exists before test (Figure 34). Increased membrane thickness appears to be a better lifetime extender than reinforcement for these before-test irregularities. This is an extremely important finding related to the continuing industry trend toward thinner membranes, as well as for the continued increasing emphasis on heavy-duty fuel cell applications, where much longer cell lifetime is required. [Q2-20]

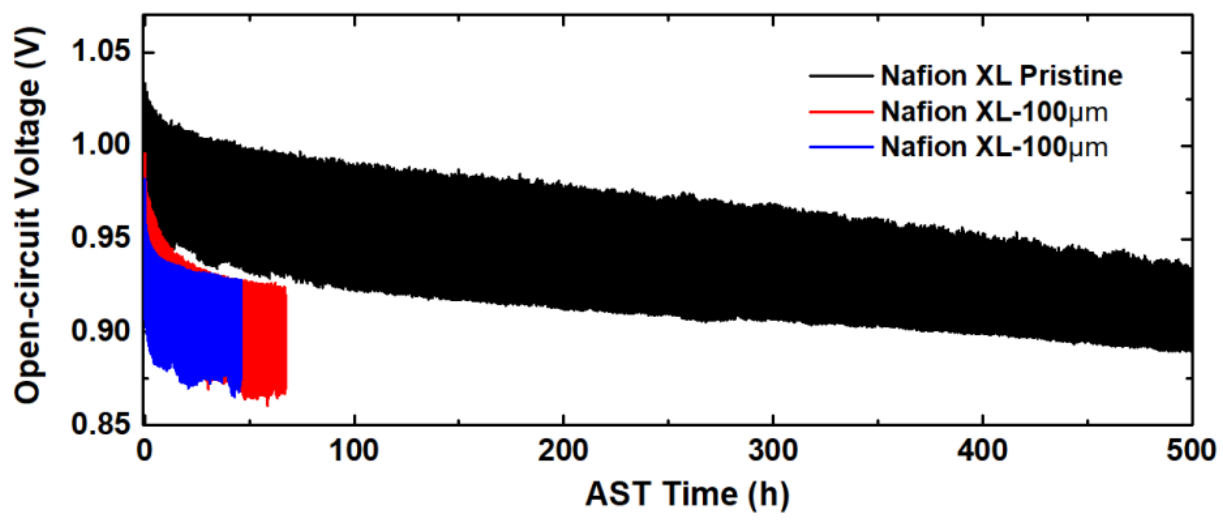

Figure 34. AST testing of replicate Nafion XL MEAs with a $100 \mu \mathrm{m}$ pinhole, compared to the pristine MEA.

Two manuscripts are currently being pursued documenting the "warm spot" work described for Task 3, however neither have been published as of the writing of this report.

In summary for Task 3, we initiated a study of the impact of membrane pinholes using three different membranes (two thicknesses, and with and without reinforcement) and precision laserdrilled pinholes, but found, in attempting to establish the baseline performance and crossover behavior of pristine cells, that all cells appeared to have small regions of hydrogen crossover ("warm spots"), even before any cell operation. The bulk of the time under this task was then spent trying to understand this phenomenon. It was found that this pre-test crossover could largely be mitigated by less intense hot-pressing conditions, though at the expense of initial performance. It was also found that these small regions of hydrogen crossover in most cases led to points of failure in the cell under AST testing. Increased membrane thickness lessened the impact of the warm spots in terms of reduction of time to failure. It was also very insightfully found that, while the AST lifetime of the reinforced membrane was many times longer than those of the un-reinforced membranes (as expected), the existence of warm spots in the cells with reinforced membrane largely negated the lifetime benefit of the reinforcement. 


\section{TASK 4: Facilitate web-line demonstrations}

NREL will coordinate with Mainstream to facilitate and support demonstration of Mainstream's full-scale prototype systems on NREL's roll-to-roll research web-line and pilot coating line.

\section{Results for Task 4:}

We hosted a visit from the Mainstream PI and project researcher, during which we held lab tours to show new capabilities established since their last visit and discussed overall plans for the project for QC development, in situ testing, and sample fabrication. However, given that the major emphasis at Mainstream during this phase of the CRADA was to develop, prototype, and commission for operation a stand-alone R2R optical inspection station, it was determined that further testing of Mainstream's devices on NREL's web-line was not required. [Q2-19]

\section{TASK 5: Project Documentation}

NREL will provide Mainstream with short monthly status reports.

\section{Results for Task 5:}

During the second part of the CRADA, NREL provided to Mainstream monthly written status reports and/or monthly web-conference presentations of status and progress.

\section{Subject Inventions Listing:}

U.S. Provisional Patent Application No. 63/030,776, "Methods for measuring the properties of complex membranes and films,” P. Rupnowski, M.J. Ulsh; Filed May 27, 2020 (Docket No. NREL PROV/20-97) (EXPIRED).

\section{ROI \#:}

ROI-20-97, Measuring thickness using interference fringe method for complex Nafion membrane configurations (HP and XL) 